\title{
Alexander the Great and Gog and Magog.
}

By E. A. Wallis Budge.

In my edition of the Syriac version of the PseudoCallisthenes $\left.{ }^{2}\right)$ I gave an English translation of a metrical discourse attributed to Jacob of Serug (born A. D. 45I, died A.D. 52I) upon Alexander the Great, and the Gate which he built in the north to shut in the people of Âgôg and Mâgôg. This translation was made from a text contained in a manuscript ${ }^{2}$ ) preserved in the Bibliothèque Nationale, Paris, and from British Mus. Add. Ms. 14,624 ff. $20 b-34 a$, col. $1^{3}$ ). The text from the Paris manuscript was published by KNoEs in his Clirestomathia Syriaca, pp. $66-107$, but contains many misprints and errors; in the footnotes to my translation I gave the result of a collation of a large number of the faulty passages in the printed text with the original manuscript, kindly made for me by Dr. Zotenberg, and added corrections of many misprints, and variant readings from the British Museum Ms. It has been regretted by many that the English translation of the discourse ${ }^{4}$ ) was not accompanied by a

1) The History of Alexander the Great, Cambridge, 1889, pp. 164-200.

2) For the description of its contents see Zotenberg, Catalogues des Manuscrits Syriaques, $4^{\circ}$ Paris, p. 199. no. 243. sect. 4 ; see also ibid. p. 4 , no. 13 , sect. 40 .

3) See WRIGHT, Catalogue of the Syriac Mss. in the British Muscum, vol. II. p. 782 .

4) For German translations see A. WEBER, Des. Mar Iaqû́b Gedicht ïber den gläıbigen König Alexandrûs, Berlin 1852, and ZINGERLE, Ein altes syrisches Alexanderlied (privately printed), Brünn 1882.

Zeitschr. f. Assyriologie, VI. 
new edition of the Syriac text, especially as the little chrestomathy of $\mathrm{K}_{\text {NOES }}$ is old and not easily to be obtained, and because the additions and variant readings in the British Museum Ms. are of considerable value for the study of this version of the Alexander Story. In the following pages the Syriac text given is that of Add. 14, 624, and I have only ventured to make alterations in cases where the scribe has palpably blundered. The divisions of the lines, frequently unmarked in this Ms., have not been changed, and several superfluous words, the presence of which is probably due to the carelessness of the scribe, have been retained, because they may serve to indicate the correct readings as other manuscripts of this discourse become available; neither the Paris nor the London Ms. can be considered to contain a satisfactory text, although each has a special value. In the notes "P." represents the Paris Ms., and "L.", Brit. Mus. Add. 14,624.

The contents of this discourse are of importance for the study of the Alexander Story, and find their parallel chiefly in the Greek Codex of Pseudo-Callisthenes called C (Müller, p. VIII, col. 2, Introductio); certain passages, however, agree with the. Ethiopic version of Pseudo-Callisthenes. These passages are not commented upon in any way here, because I hope, at no distant date, to publish the complete text of the two chief versions of the Alexander Story in Ethiopic, when the identity of the passages will be evident, and a final discussion as to their origin possible. 


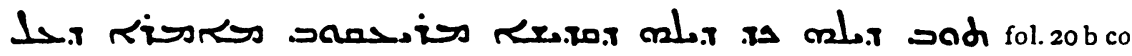

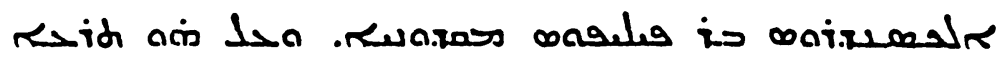

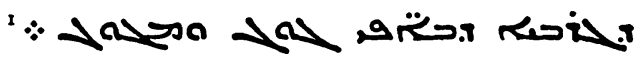

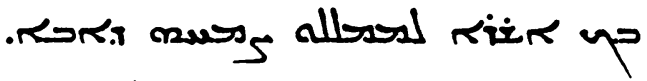
2 5

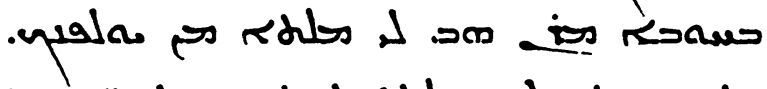

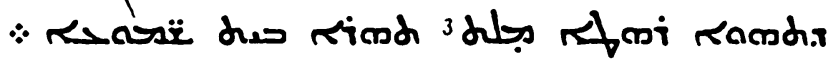

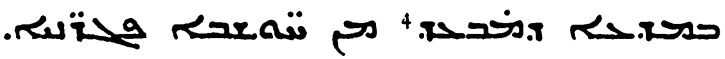

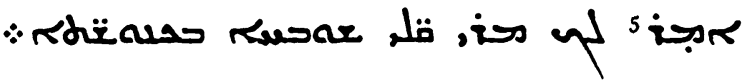
10

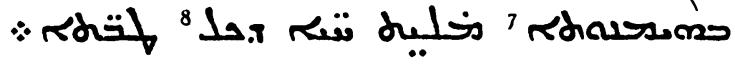
"20.

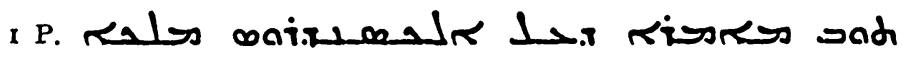
תمسديم محل $\therefore$ : > > 2 L. omits lines 4 and 5. - 3 L. . 4 P.

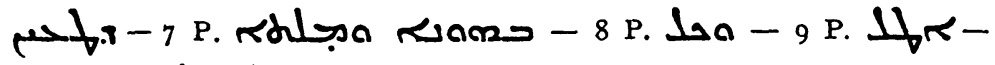
ro P. diare حل. 
$\therefore$ Risar duts ydomas stidas "rena

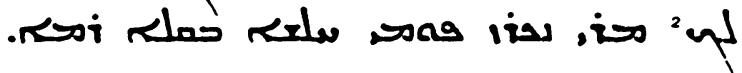

fol. $20 \mathrm{~b}$ col. 2 $\therefore$ : 15 ل

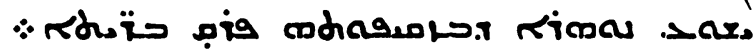

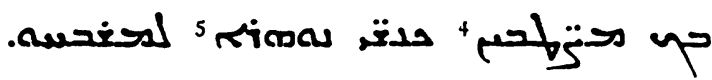
sais 20

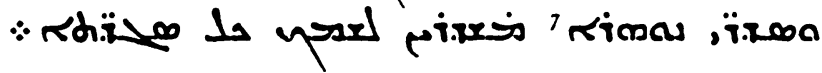
حتن,

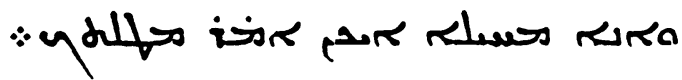

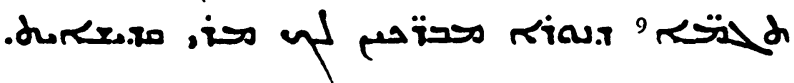

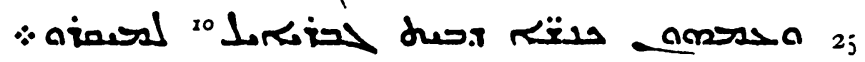

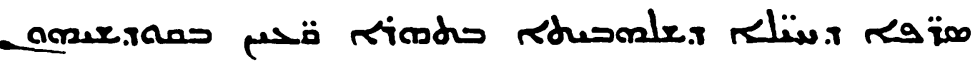
$\therefore$ م "11 $\therefore$ upar ||

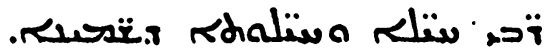
30

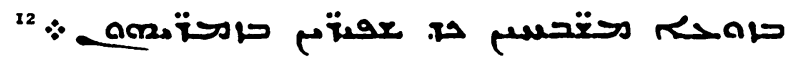

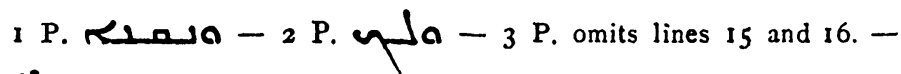

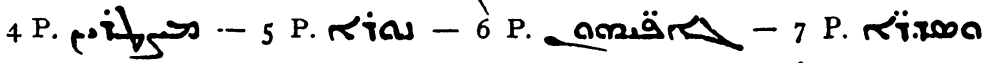
rias. - 8 P. 9 P. - 9 P. II In $P$. the equivalent of lines $26-28$ is

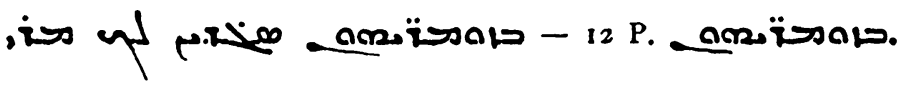




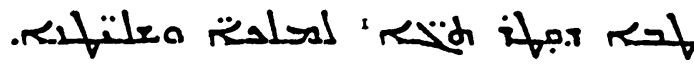
$\therefore$ onale " $\therefore$ onale 35

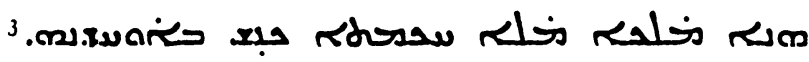

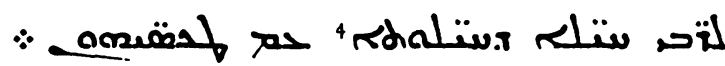

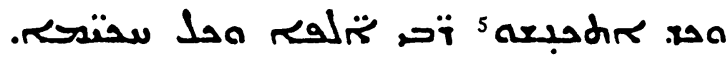

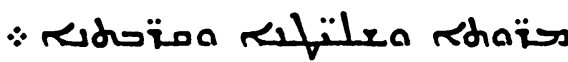

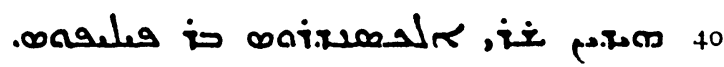

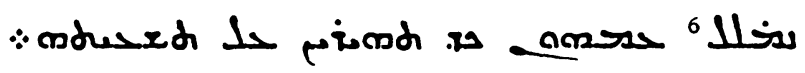

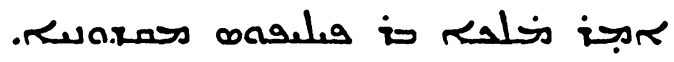

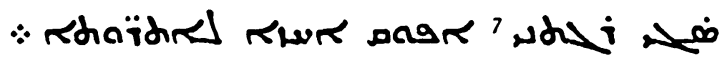

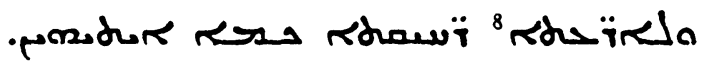

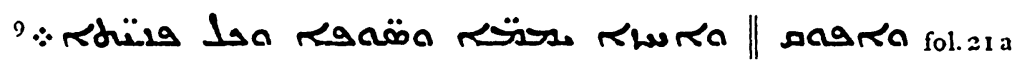
תمo אمי "

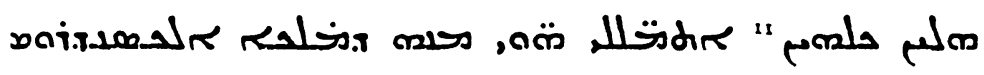
${ }^{12} \cdot$.

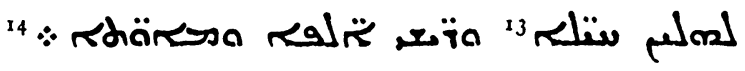

1 P. «재 - 2 P. omits lines 34 and 35. - 3 P. msward

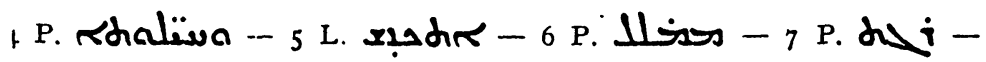

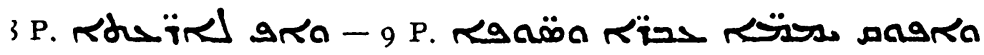

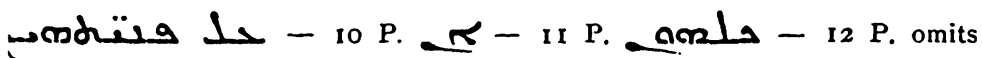

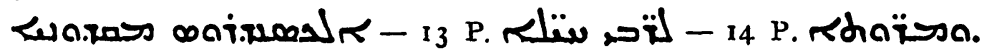




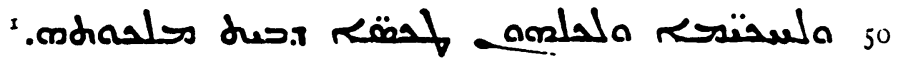

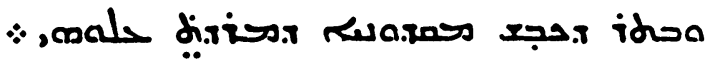

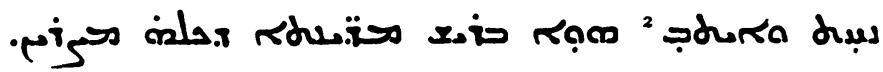
a مat

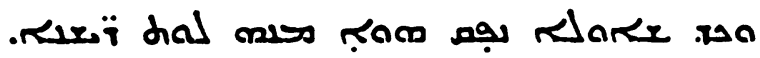
" : 55

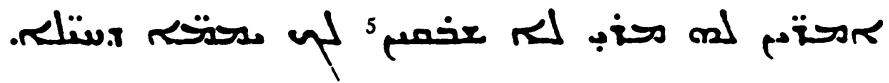

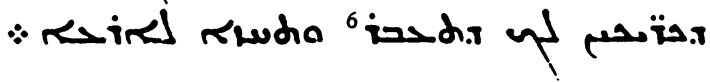

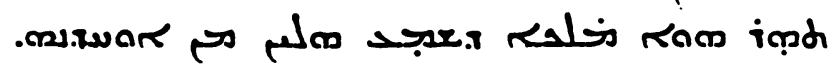
2 I b col. I

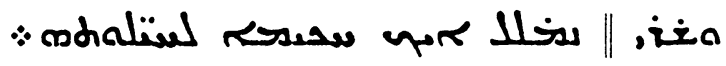
8. 60

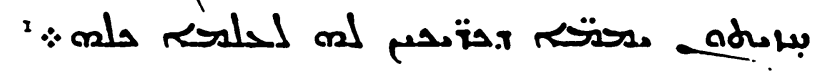

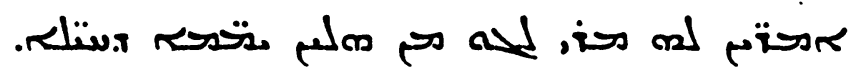

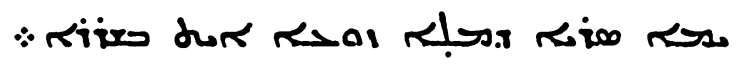
مrلم " 65

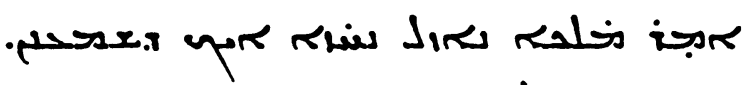
" rosis

I P. omits this line. - 2 P. Jגם - 3 P. గ Rd - 4 P. ra

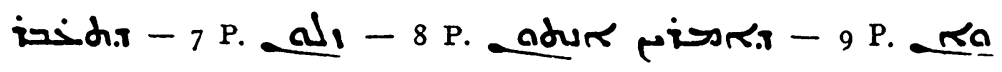

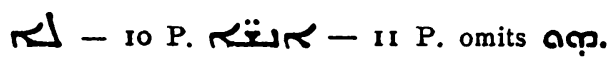




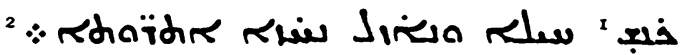

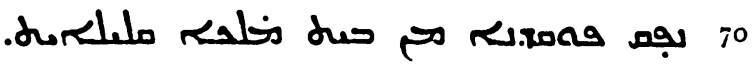

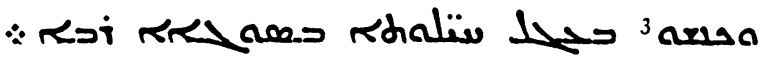

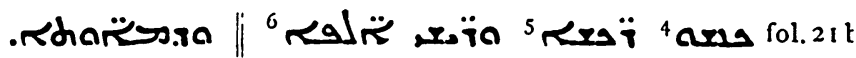
9 آهـال ت تصمא

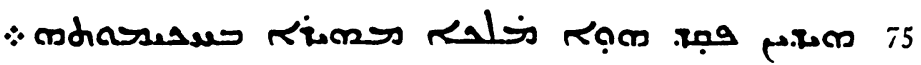

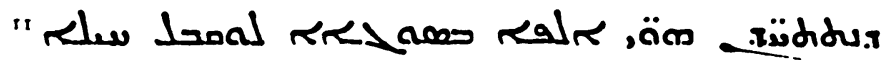

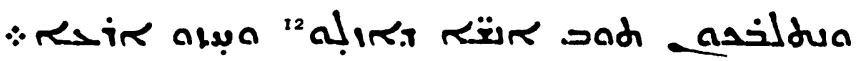

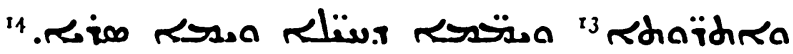
$\therefore$ mbialied

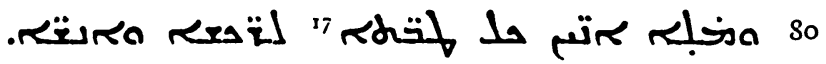
sis "N,

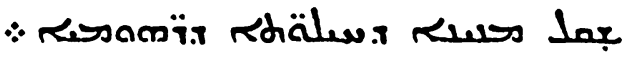
ت̈لم א

I P. ת.2 - 2 P. Rhoïdirs] - 3 P.

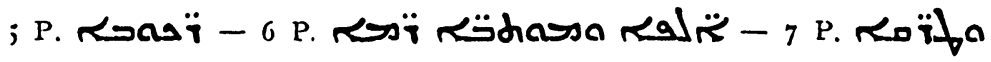

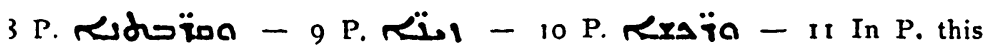
ine runs: -

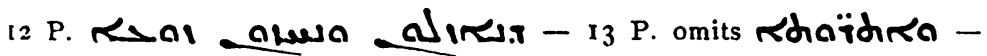

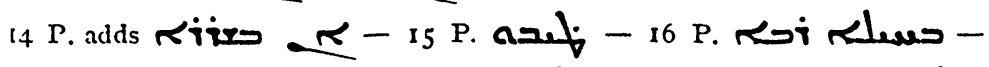
17 P. sل

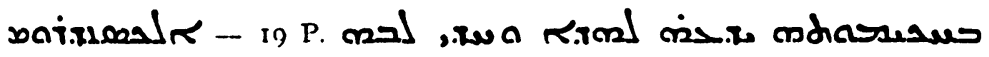
so P. Kls rishs. 
fol. 22acol. I 8 85

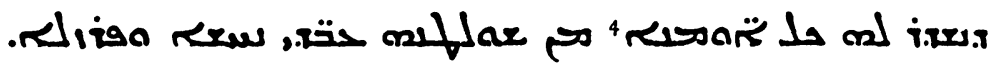

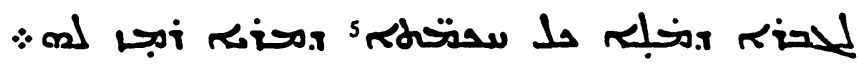

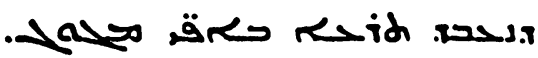
$\therefore$ Khasarar 90

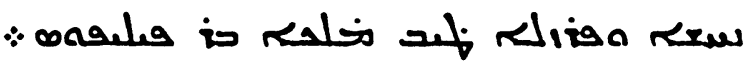

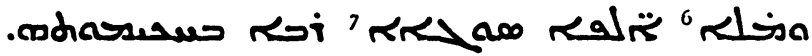

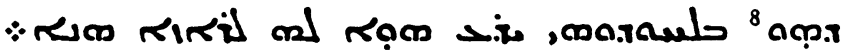

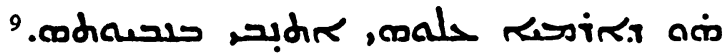
$\therefore$ onale is 95

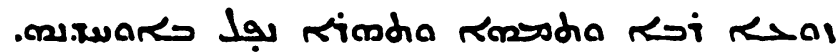

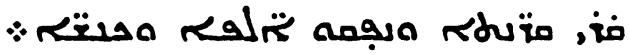
${ }^{10}$. ol. 22 a col. 2

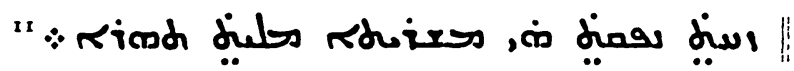
ז2. 100

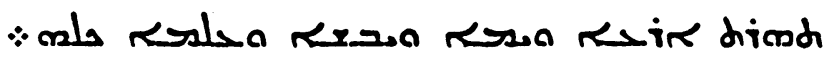

I P. $\mu$ lea - 2 P. omits $a$ - 3 P. alvays a

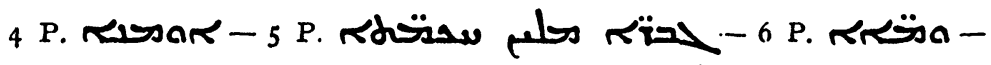

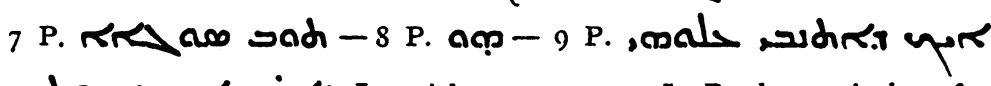
mbiarsiriar Jeremiah I. 14. - 10 In P. the equivalent for lines $95-98$ is: -

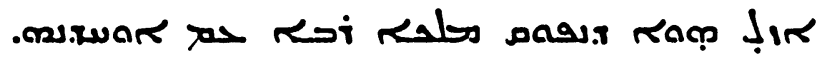

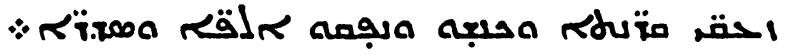
II P. Rals india - 12 P. mdialw. 


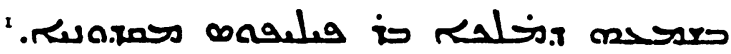
אוֹ

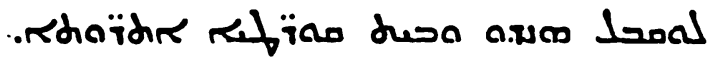
3\% 105

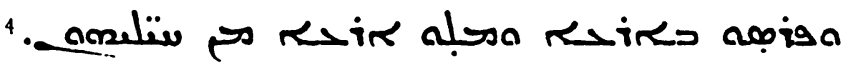

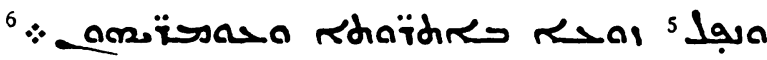
תم

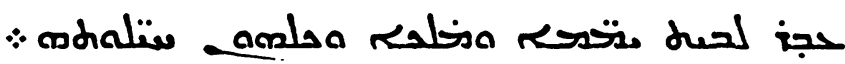
مו 7\% fol.22b

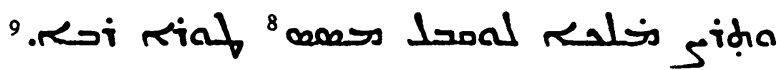
olv "م "

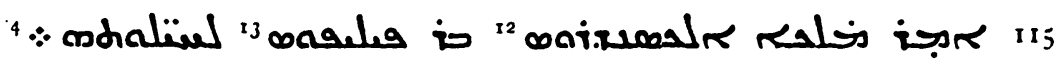

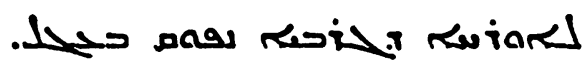

I In P. the equivalent of lines 101 and 102 is: Rir diosh

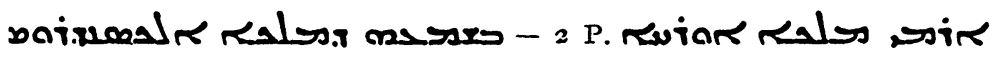

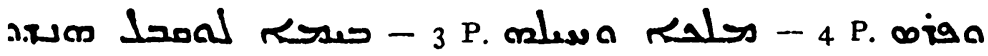

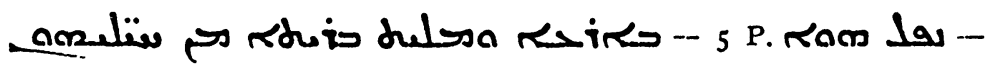
; P. Am a

orito

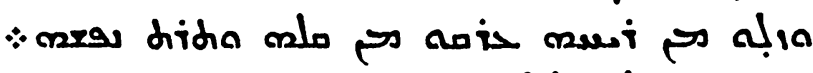

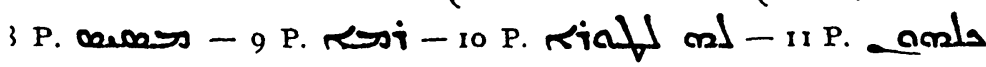

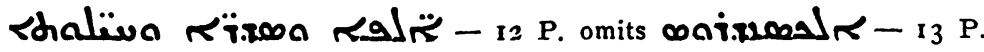
idds resa.xas - 14 P. Rs iands rialivel. 


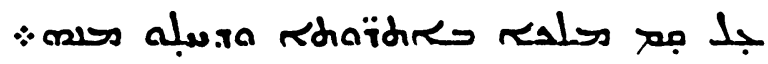

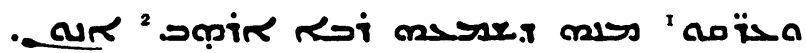

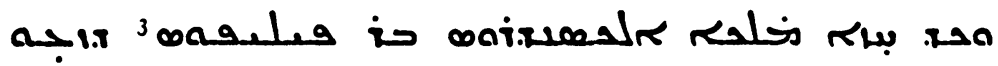
4 a a ans

120 \% 6 a

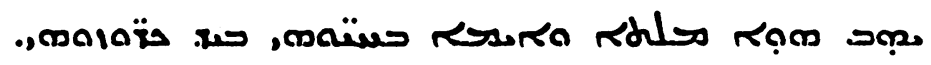

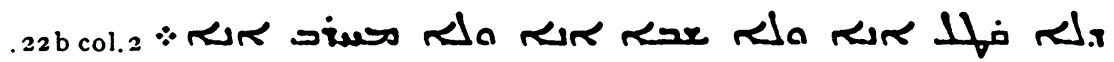

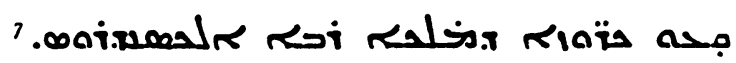
:

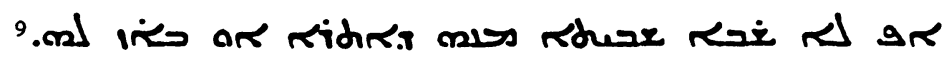
هلe

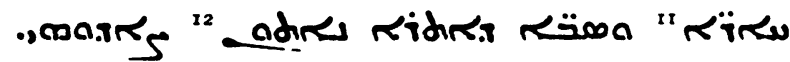
13.

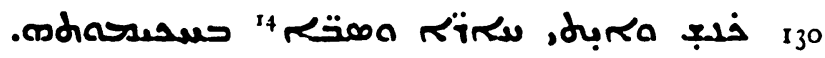
${ }^{25}:$ Ridirs, malrio

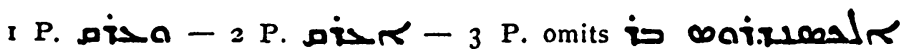

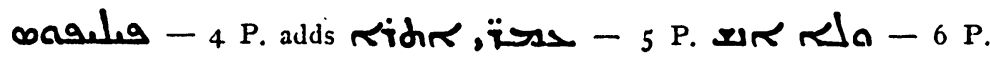

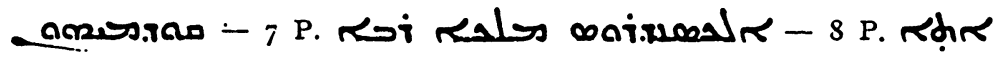

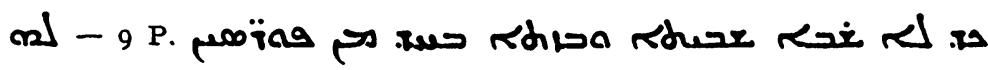
10 P. هغ

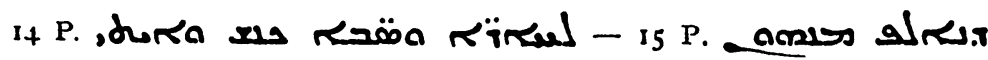

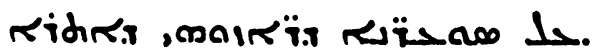




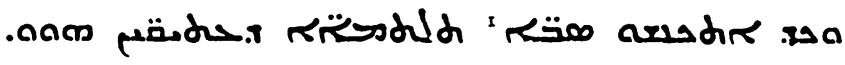

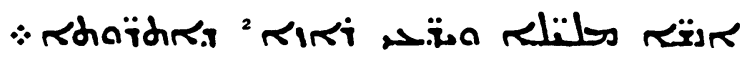

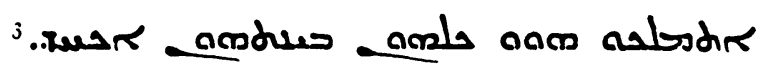

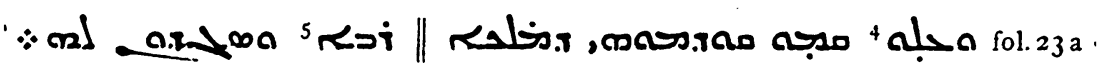

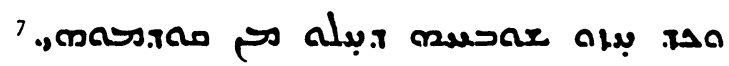

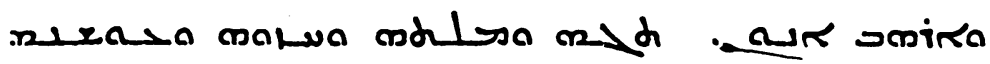
$\therefore$ mhaicas

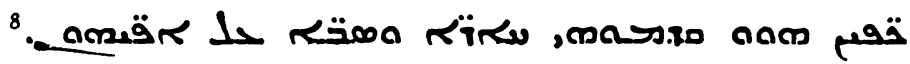

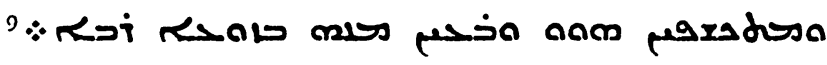

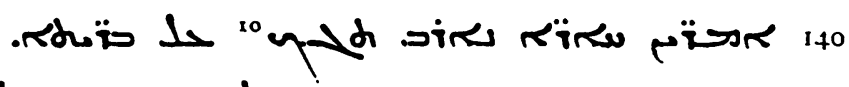

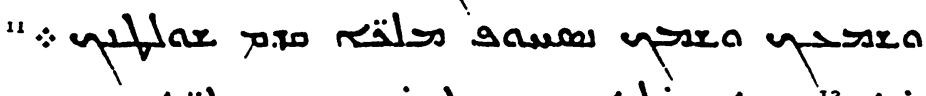
نxis

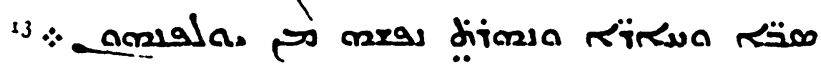

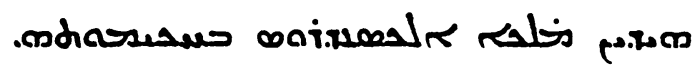
${ }^{14}:$ م 145 as.

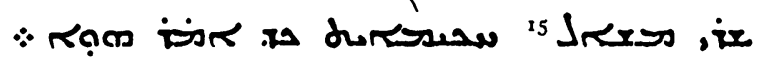

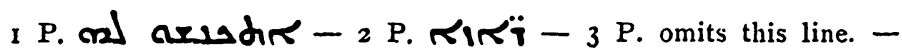

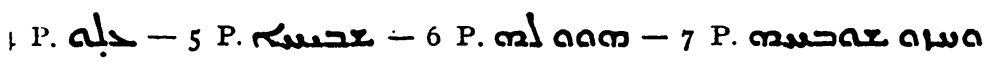

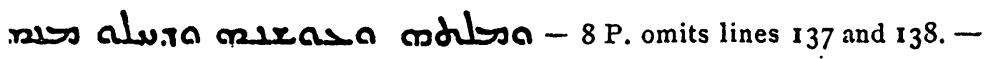

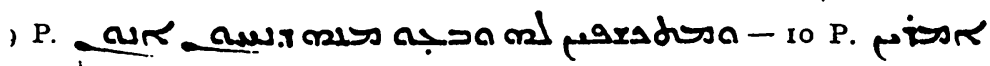

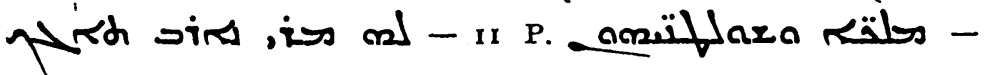
12 P. , . 00 - I3 P. omits this line. - I4 P. in the place of lines 144

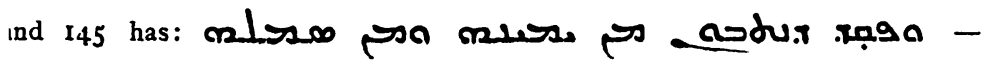
:5 P. ل Jorss. 


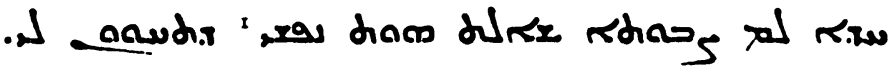

fol. 23 a col. 2

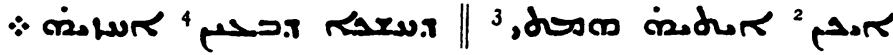
150 ז.

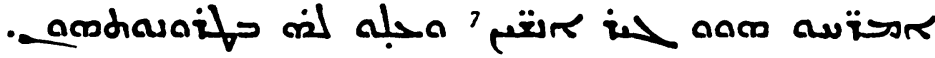
8 : אنs

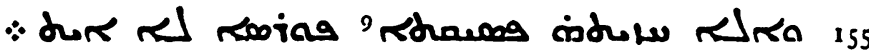

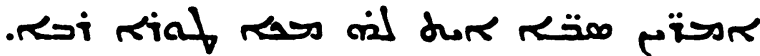
م

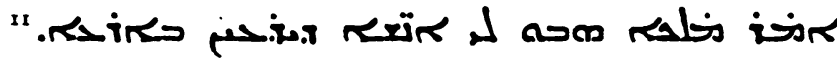

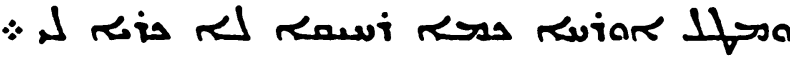
160 ת. fol. 23 b col. I

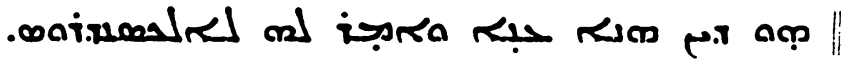

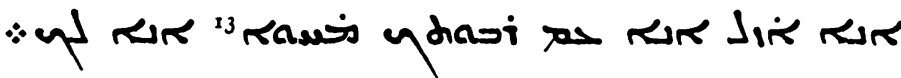

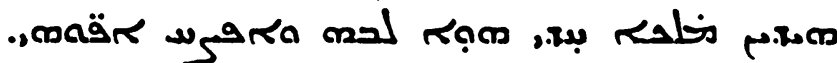

1 P. השת - 2 P. 3 P. dass -

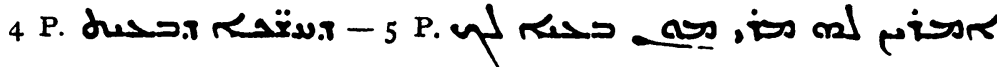

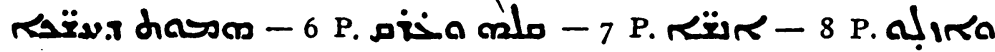

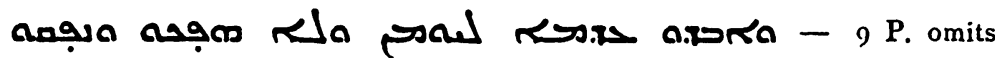

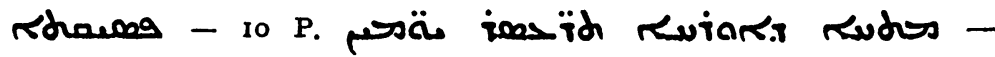

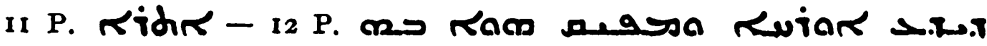

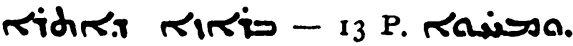


$\therefore$ مدת 165

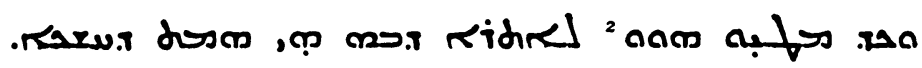

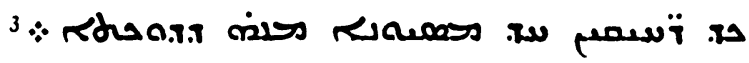

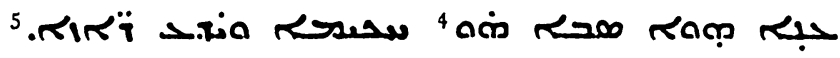

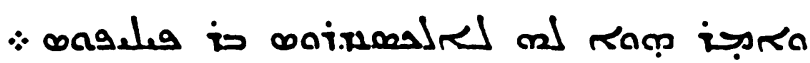
170 $\therefore$ هـ

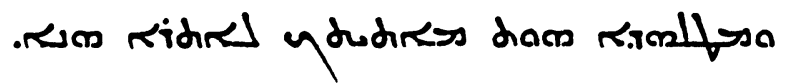

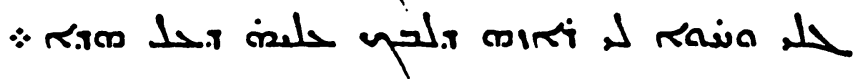

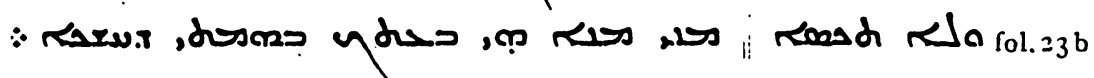

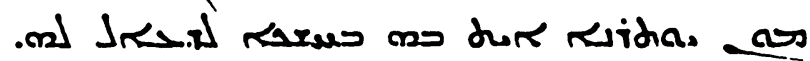
175

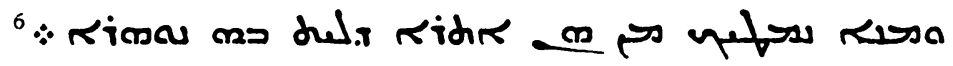

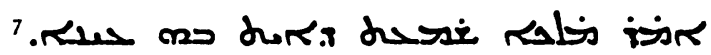

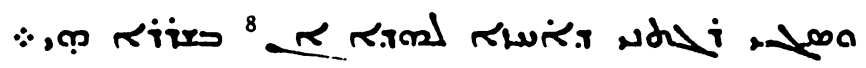

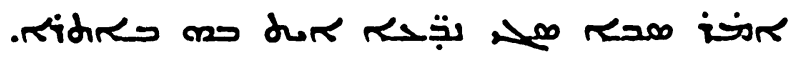
ז. 180

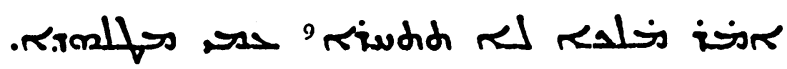

1 P. a a - 5 P. S - 6 In P. the equi-

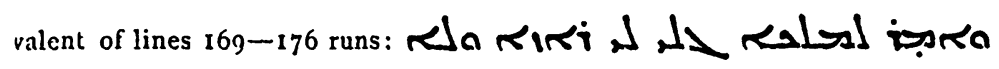

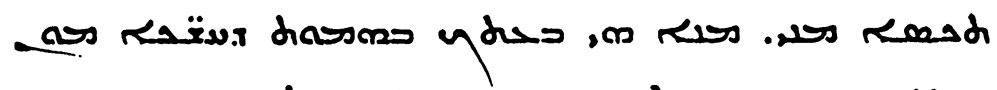

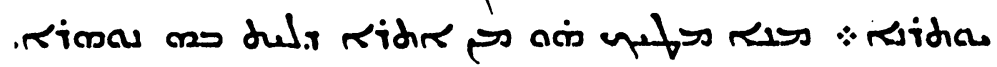
7 P. ת. 


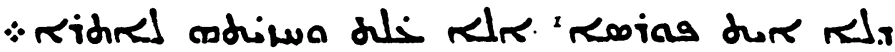

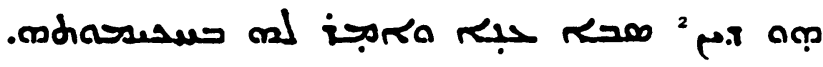
תמعل x.

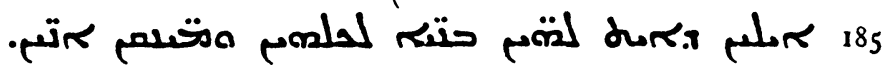

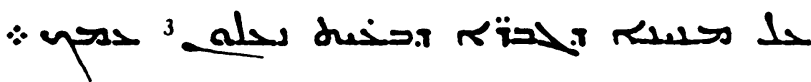
24 a col.

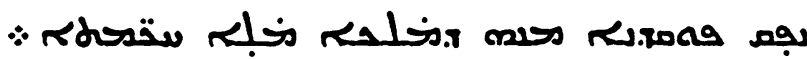
a 190

" 80 . : "10.

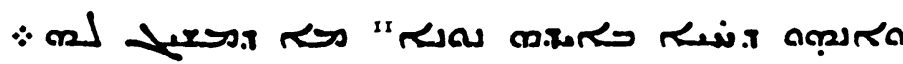

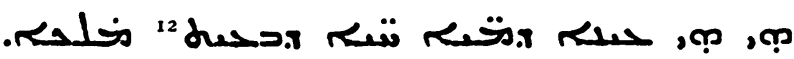

مs

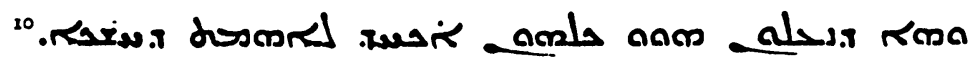

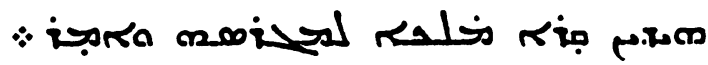

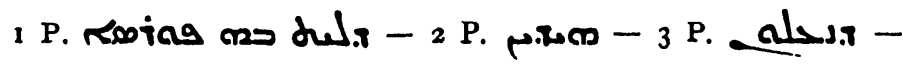
4 P. - 5 In P. lines 189 and 190 are represented by 7 P. omits rọ - 8 P. -

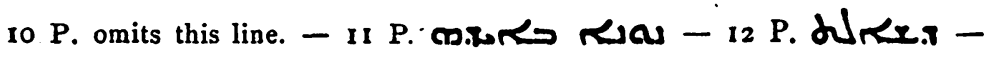
13 P. תم: 


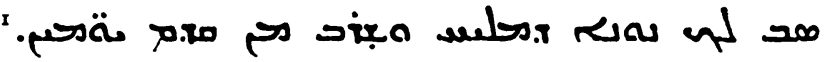

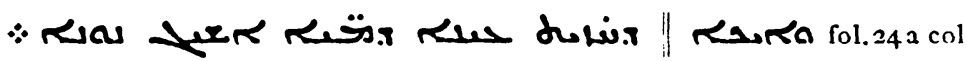

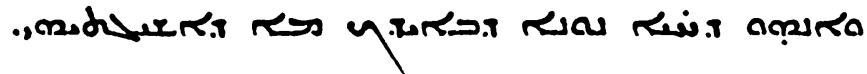

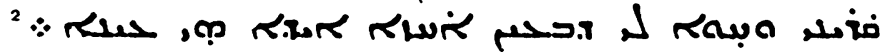
مrid

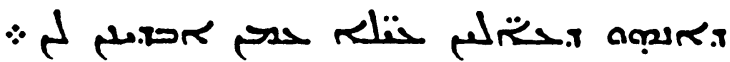

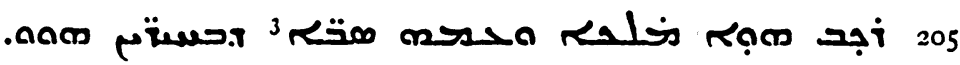

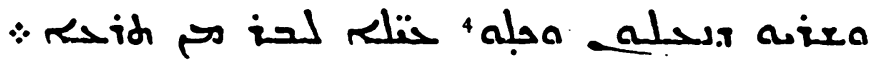
מחמתم ${ }^{5}$

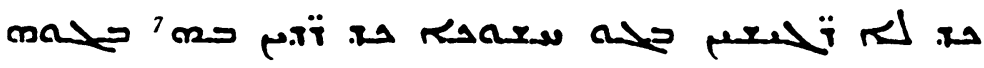
$\therefore$ గidin.

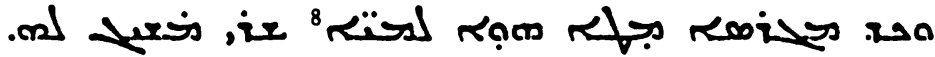
210

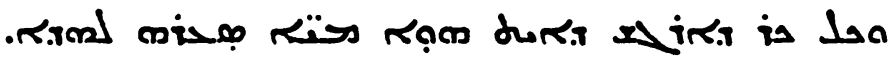

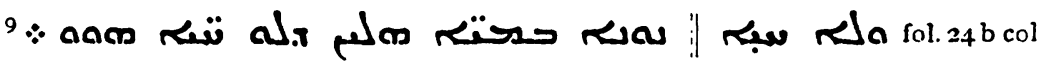

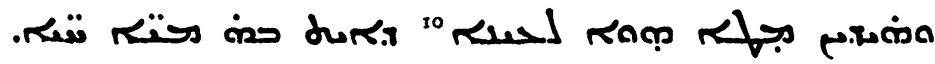

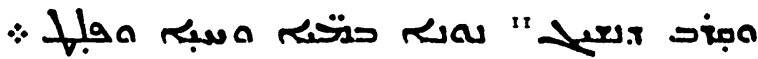

I In the place of lines 198 and I99 P. has: ل cंduser. 5 P. 8 P. 212. - 10 P. R12s] 
215 م.10 215 ז.

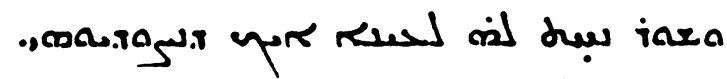

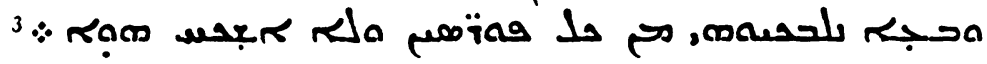

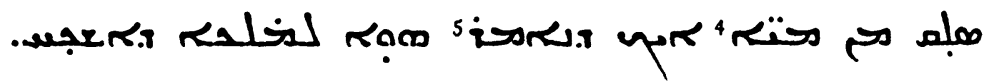

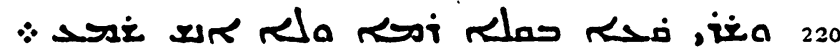

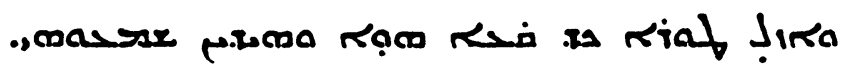

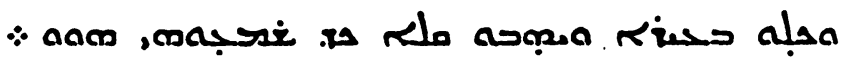

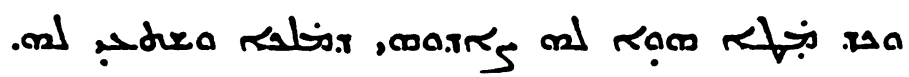
$31.24 \mathrm{~b}$ col. 2 "

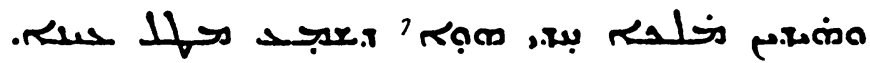
225

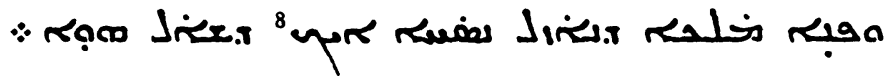
مro "x

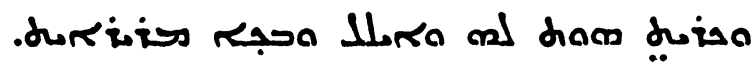
$\therefore$ - 230

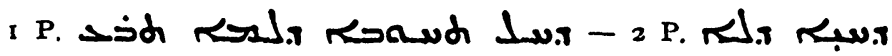
rdLe s - 3 In the place of lines 217 and 218 P. has: iara

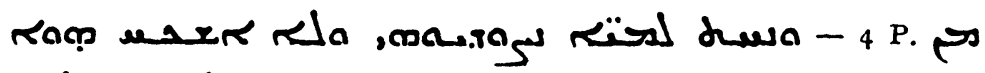
S

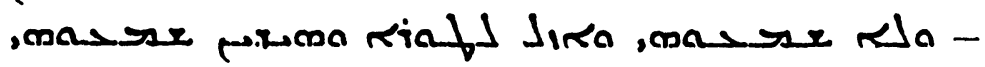
7 P. נדلم

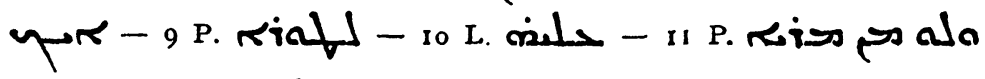

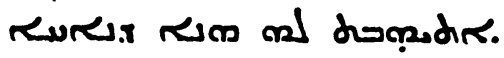




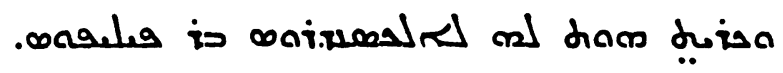

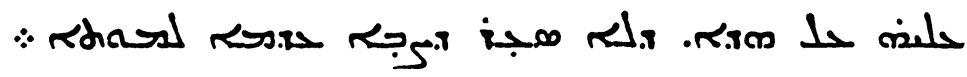

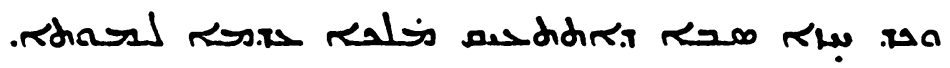

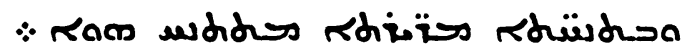
(ס) fol.25ac $\therefore u$ لriad

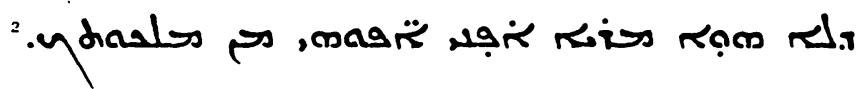

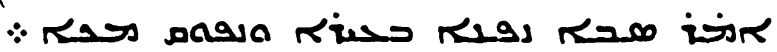

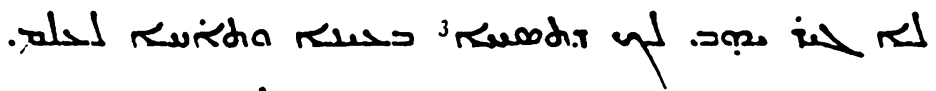
t 440 s.

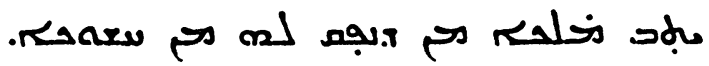

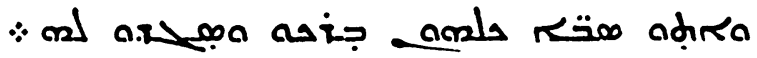

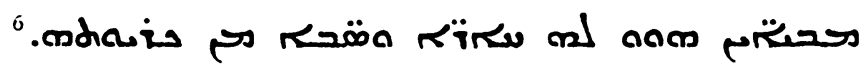

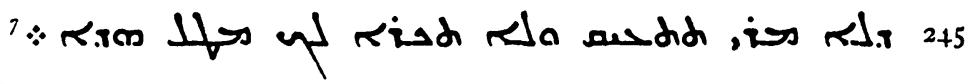

I In the place of lines 231-232 P. has: ise on diam dusan shasl '. has:

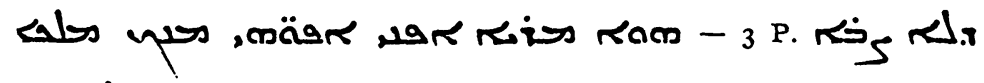

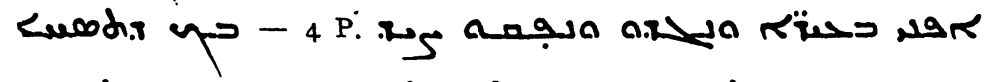

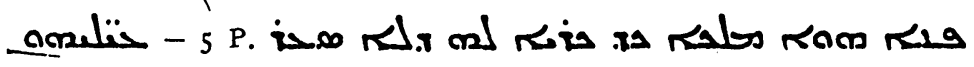
<ha $S_{5}-6$ In the place of lines 243 and 244 P. has: a ạr

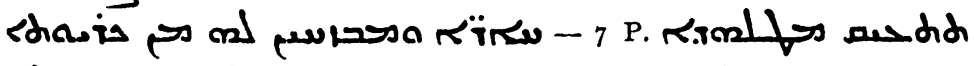
१ riad rua. 


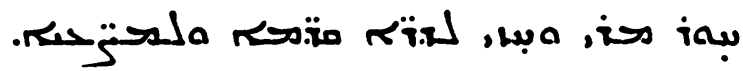

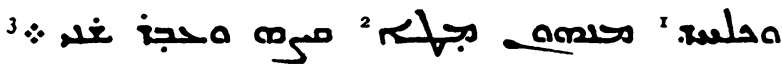
s

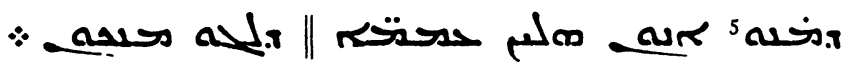
250

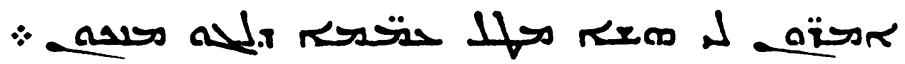

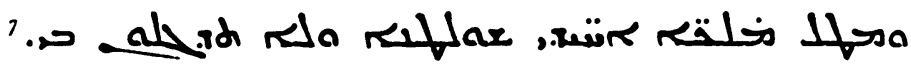

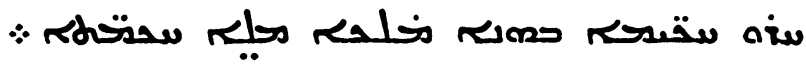
دתم 101 $\therefore$ ap 955

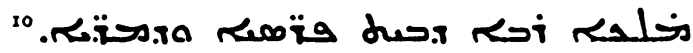

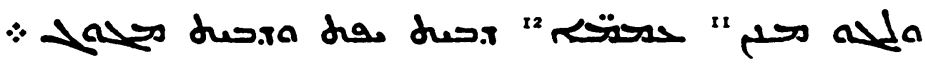

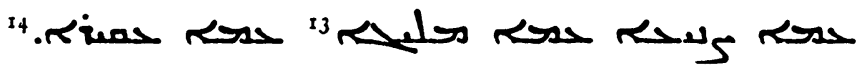

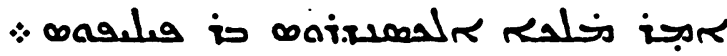
260 16 onialala rims daل 

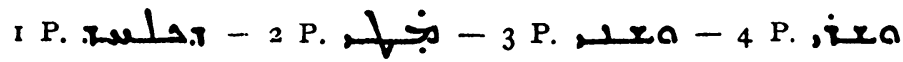

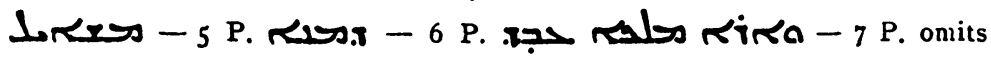

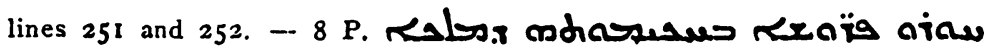
i

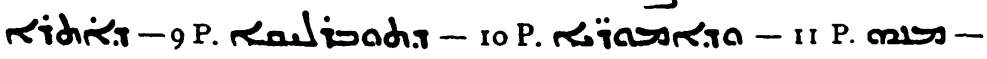
12 P. حدمي - 13 P. - 14 P. In - 15 In the place of lines 259 and 260 P. has:

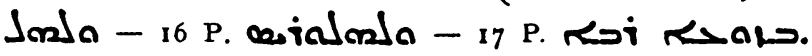




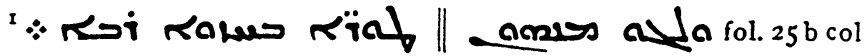
זمب0

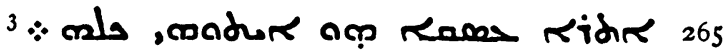

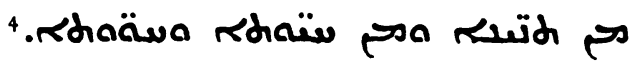
$\therefore$ مran له s : 7 . 270.

همr: . مa aldo

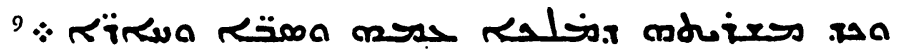

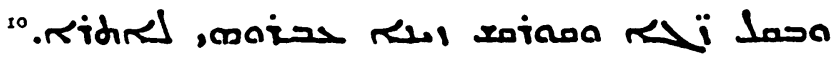
$\therefore$ rimd w 275

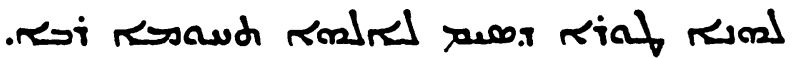
$\therefore$ oral. a sol. 25 b col.

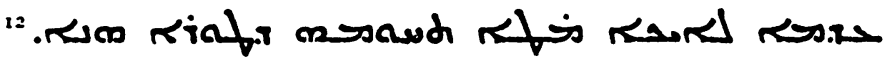

I P. Ri ksaud R.

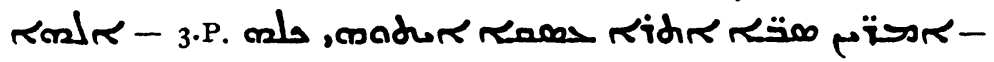

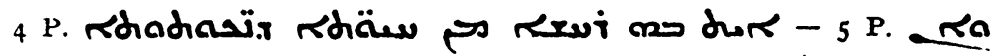

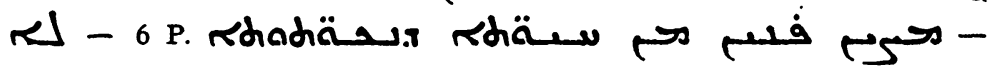

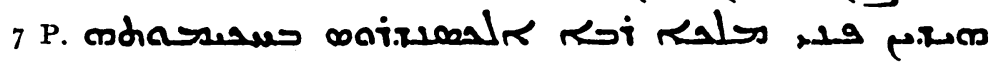
Qחبr. 9 P. omits lines 272 and 273. -

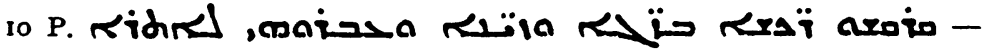

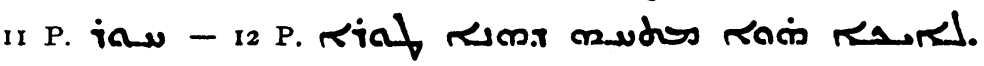




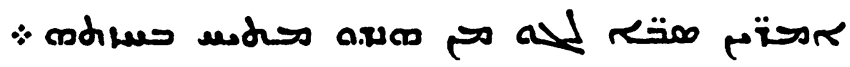
280

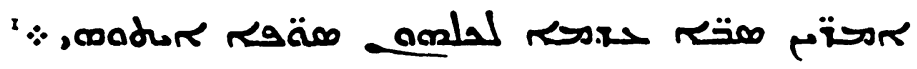

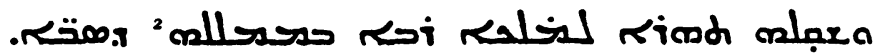

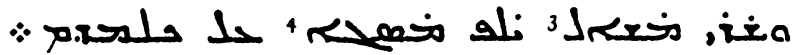

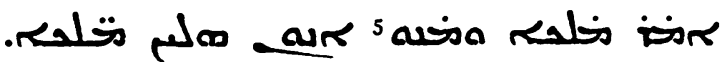
$\therefore$ مा 285

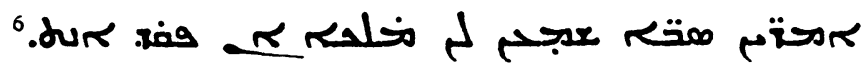

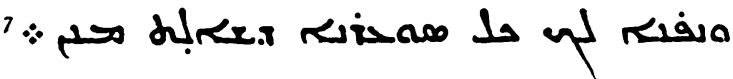
ז.

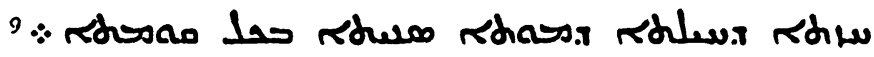
26 a col. I 290

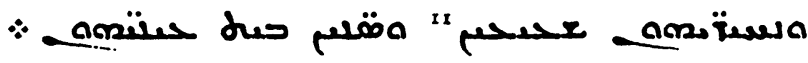

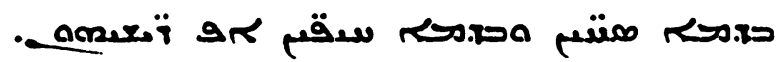
12 م.s

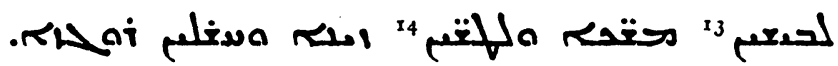
15 : 295

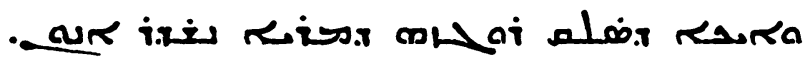

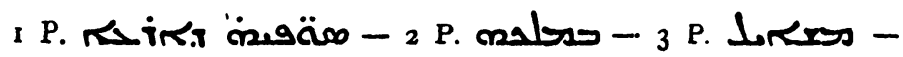

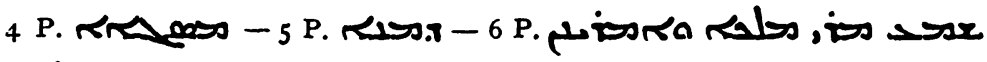

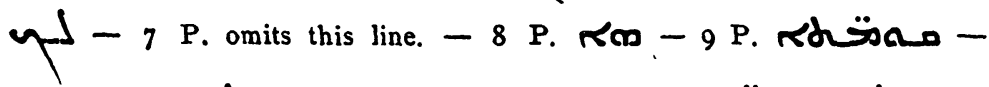

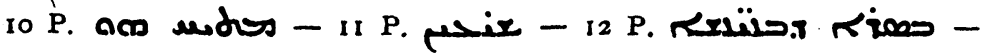

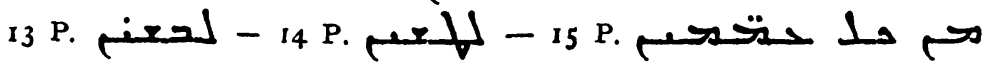
ac⿴囗十). 


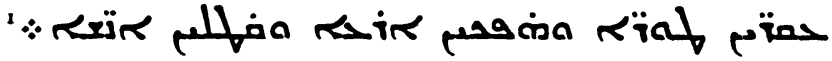

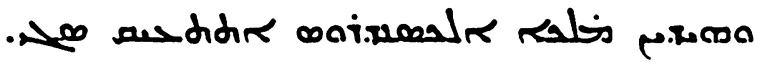

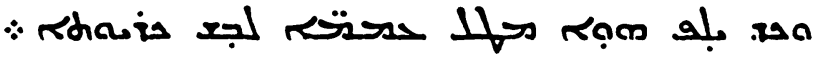
joo

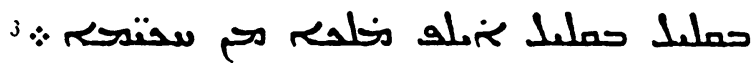

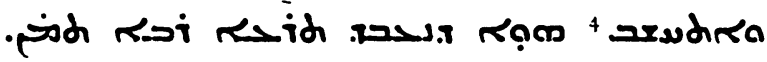
$\therefore$ معلم sol. 26a c1

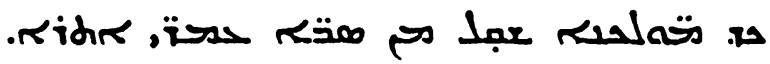
305 אח

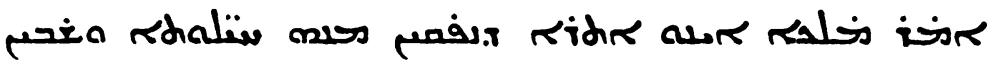
$\therefore$ Ridir

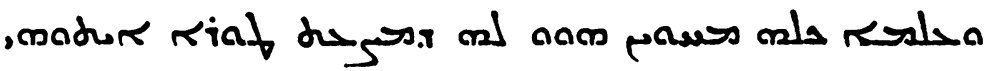
${ }^{8}$.ridir

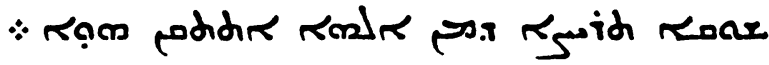
310

1 P. -

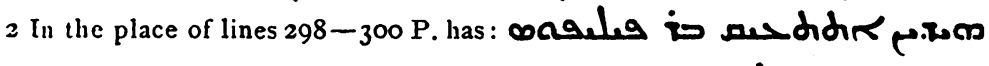
- -

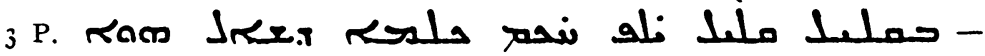
4 P. గnd -8 In the place of lines 307 and 308 P. has: -

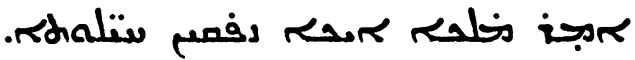

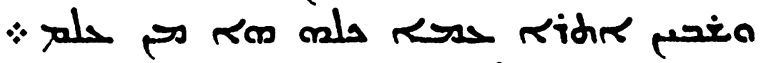

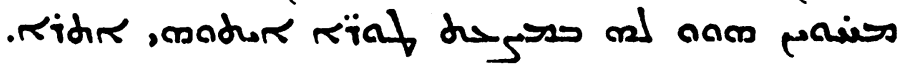




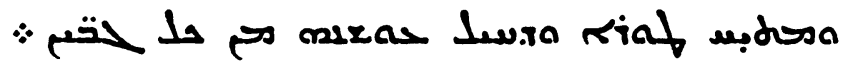

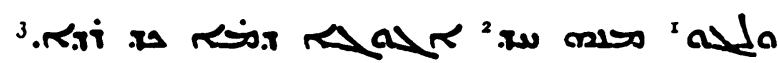
ara

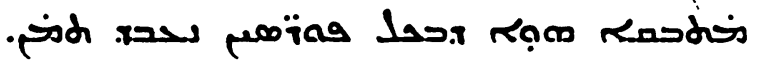
$26 \mathrm{~b}$ col. 1

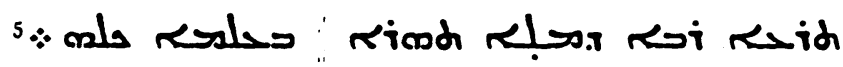

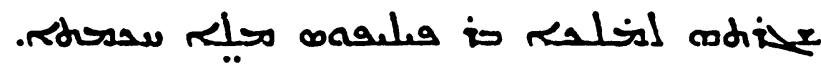

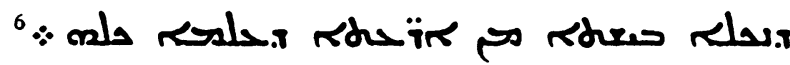
متلعم ${ }^{7}$ תis " 320

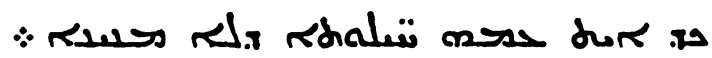

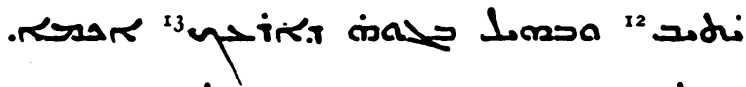

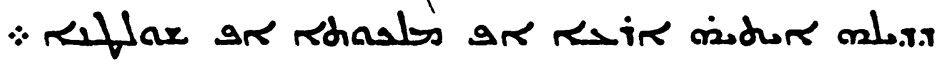

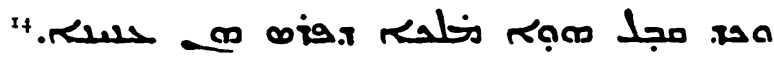

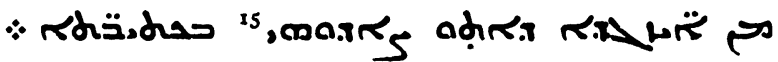

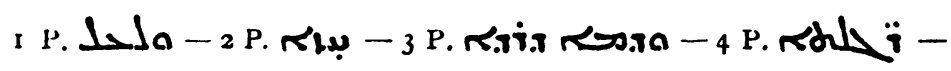

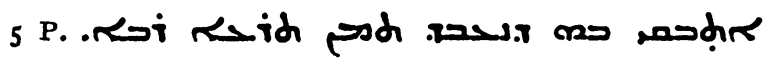

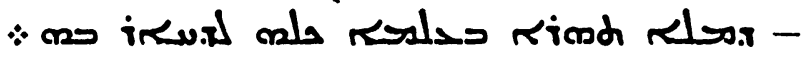
6 P. . .

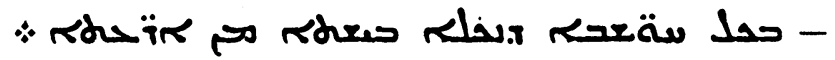

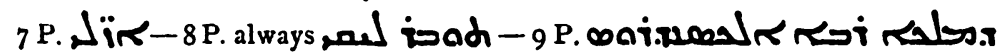

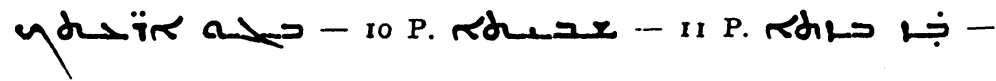

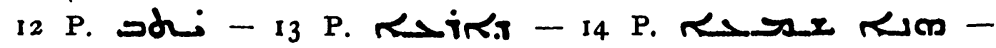

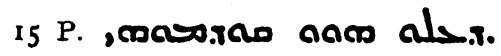


אטw.m

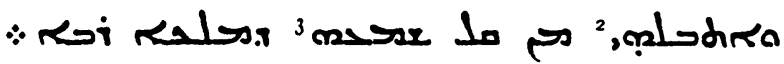


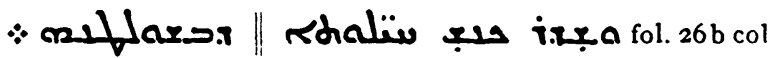

$33^{\circ}$

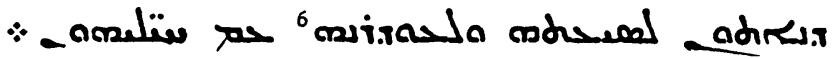

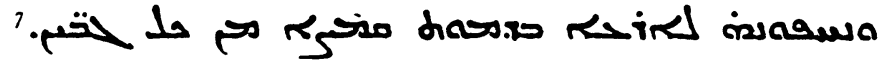

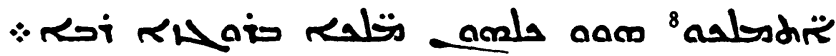

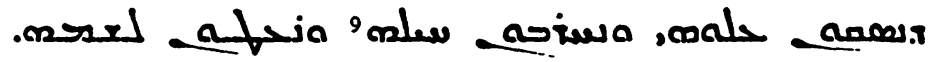

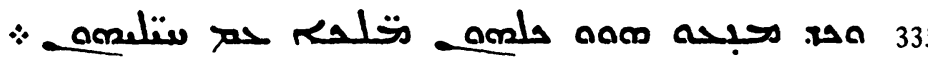

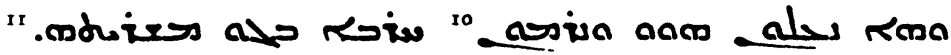
عبد

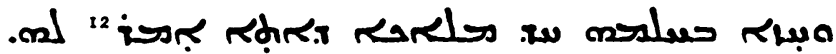
r. 340 مa

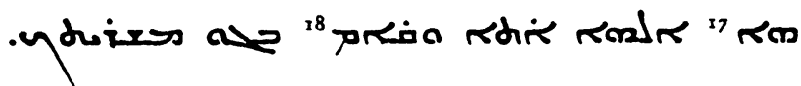

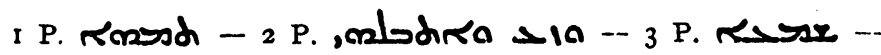

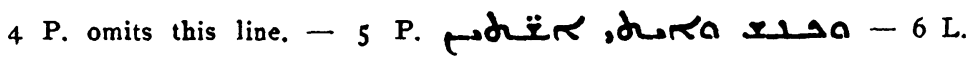

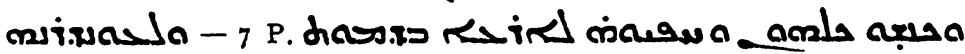
$r_{5}$ - 8 P. astadira - 9 P. smuasiusa - 10 P. a aion asisa -

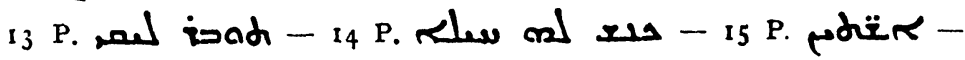

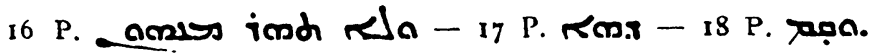


ol. 27 a col. I

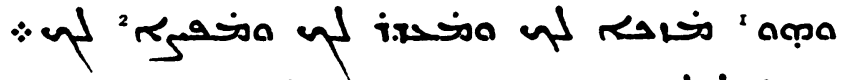

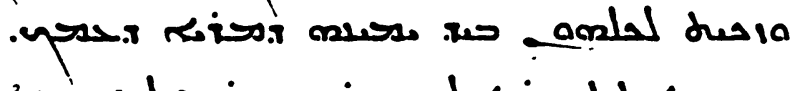
345

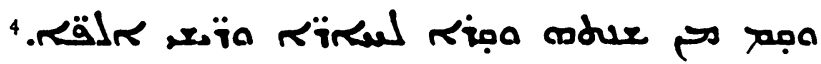

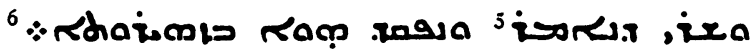
8 . ل 9 ad 350 -

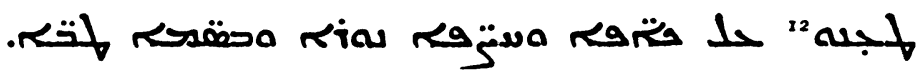

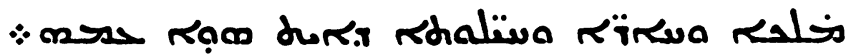

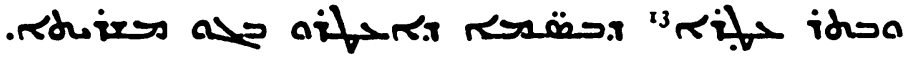
× codalien 355 ${ }^{34}$.Rodadxa R

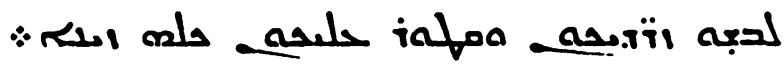
||

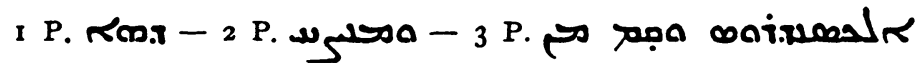

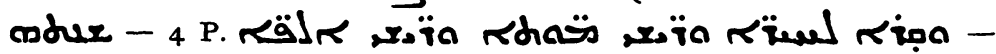

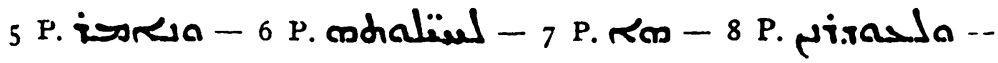

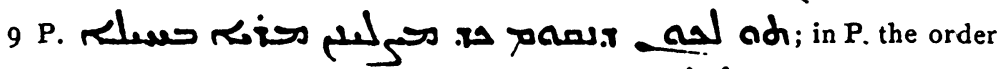
of this and the following line is reversed. - 10 P. ala

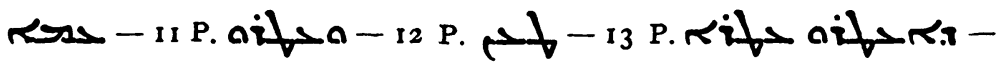

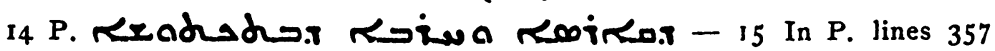

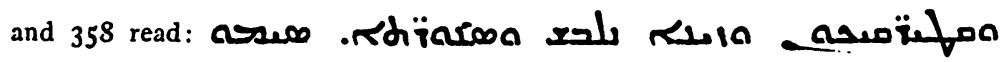

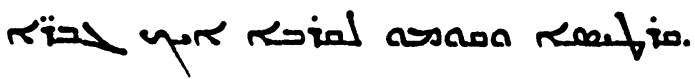




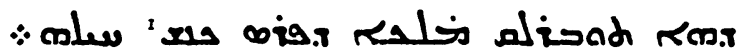
360

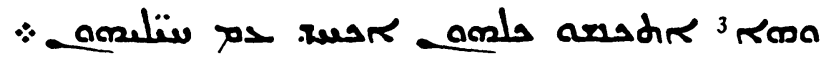

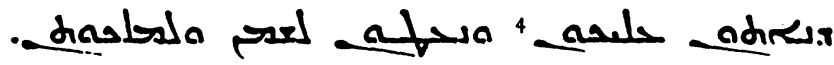
مasor

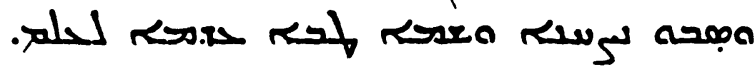

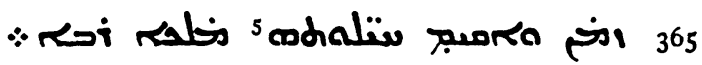
כושي

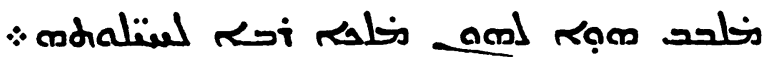

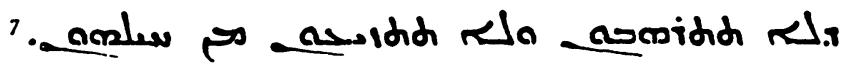

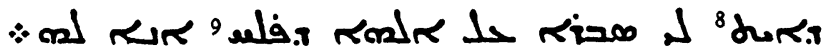
370 " " $\therefore$ Rradud t codialiel|| ||

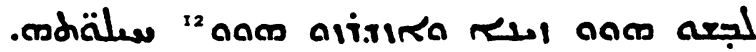

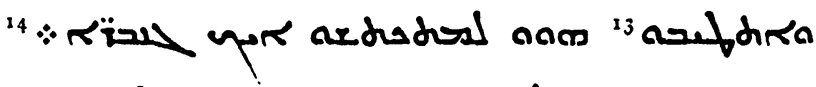
375

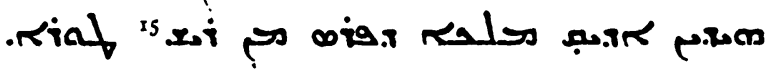

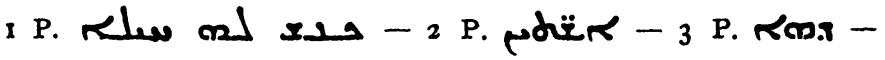

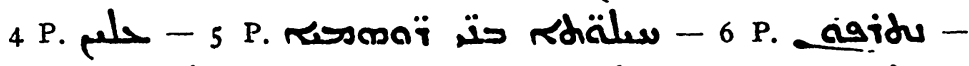

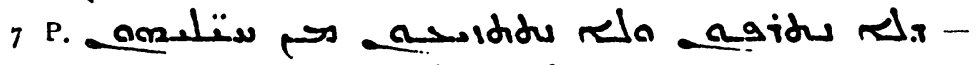

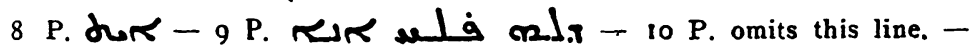

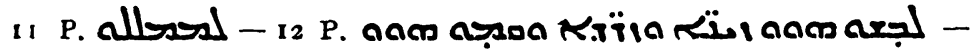

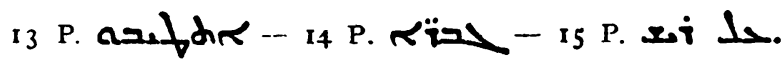




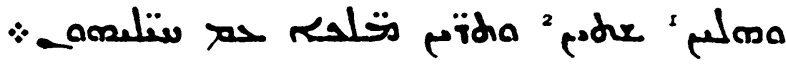

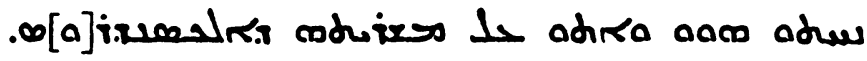

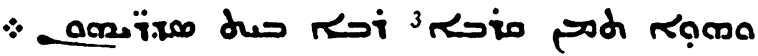

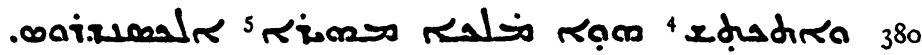

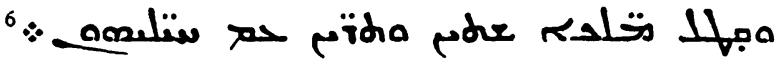

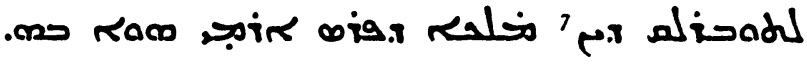

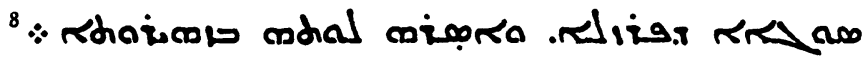

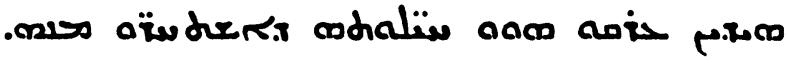

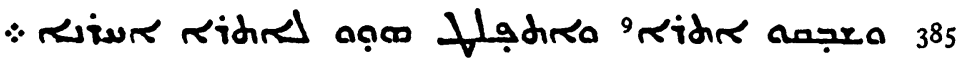

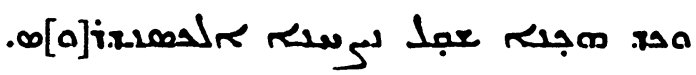

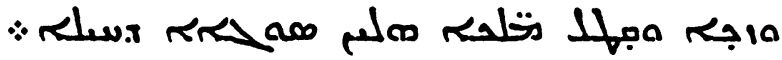
27 bcol.2 תנsليقa " 390

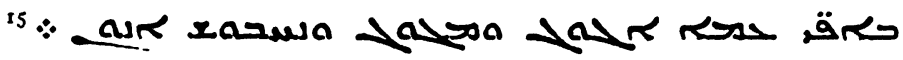

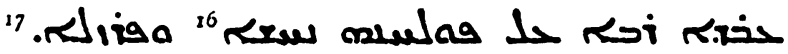

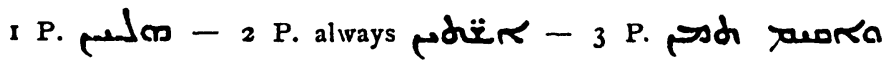

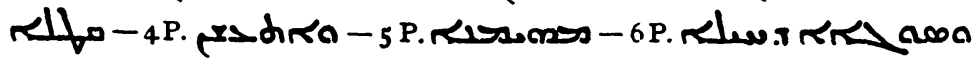
7 P. omits

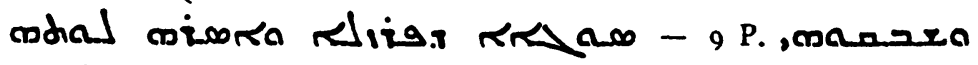
-

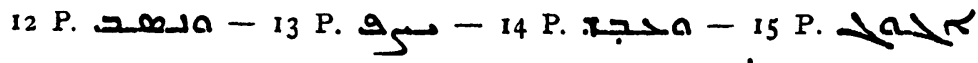

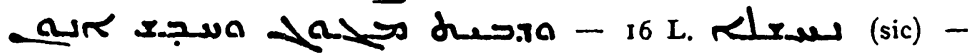

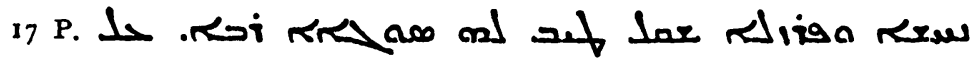
. 


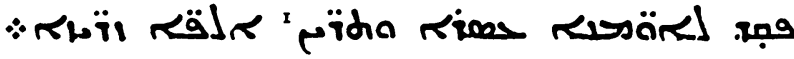

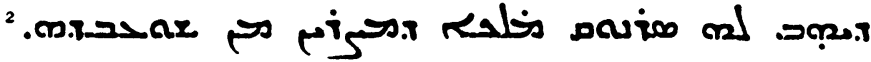

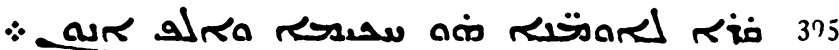

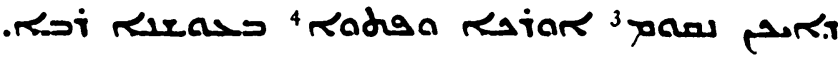

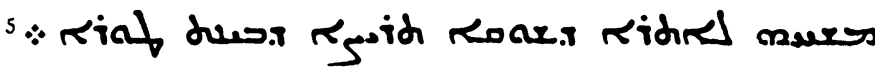

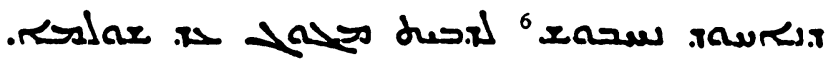

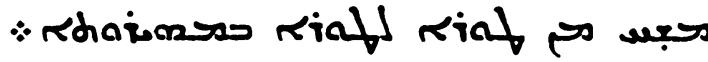
400

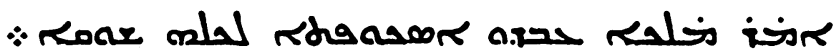

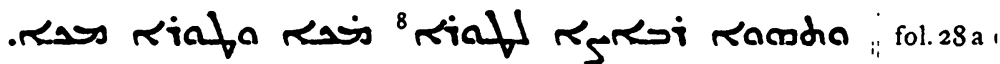

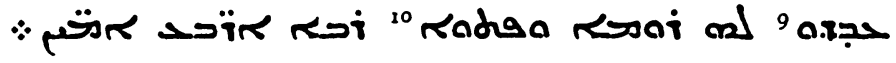

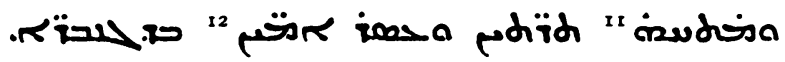

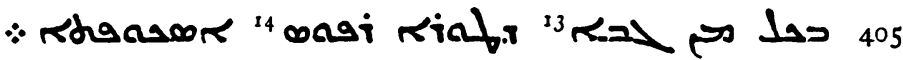

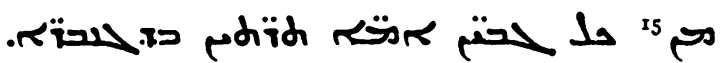
$\therefore$ Risms

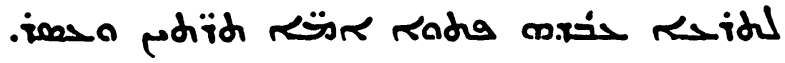

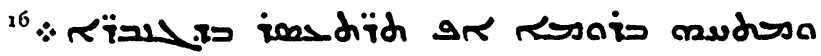

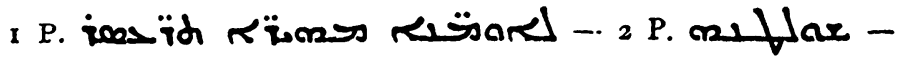

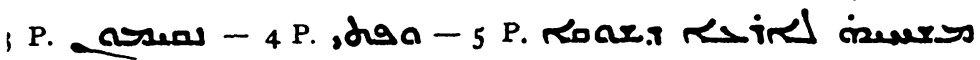

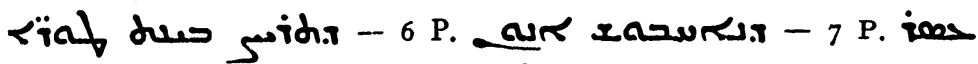

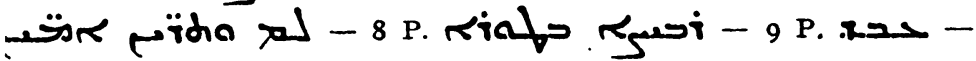

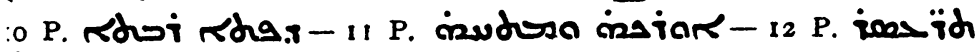

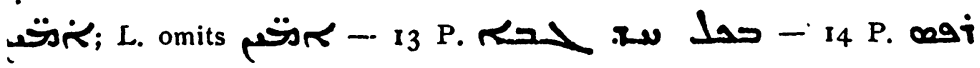
x.i ram - 15 P. pa - 16 P. omits lines 407-409. 
Rid 410

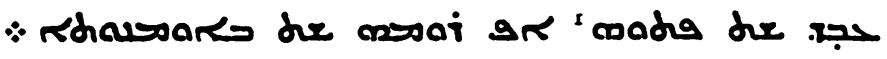

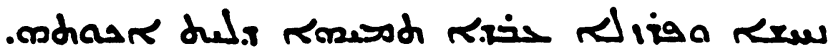
" כal ${ }^{3}$ 28 a col.2 $\therefore$ Kid || 415

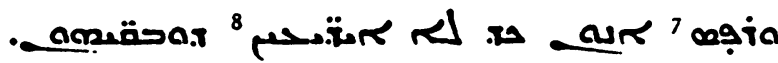

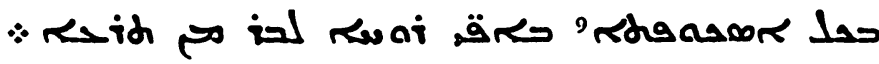

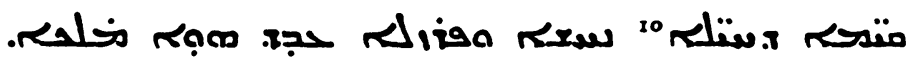

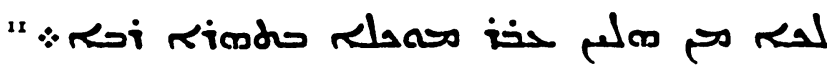

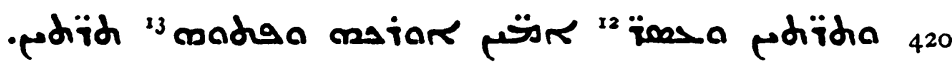
: Rdassaras

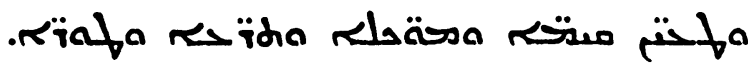

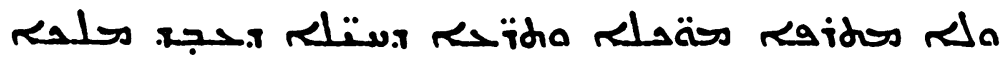
${ }^{15} \div$ :

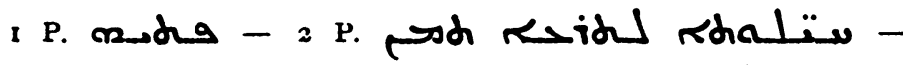

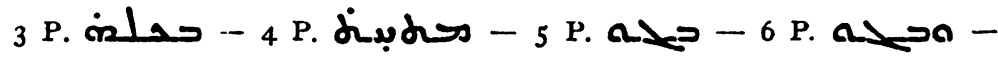

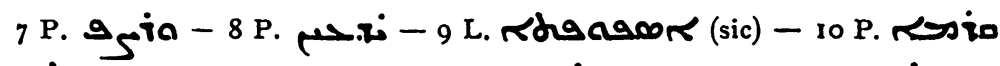

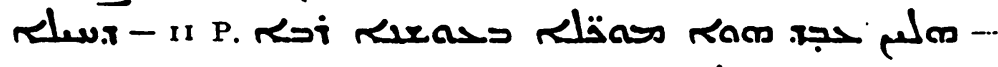

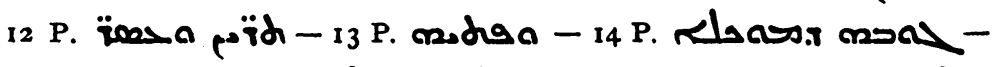

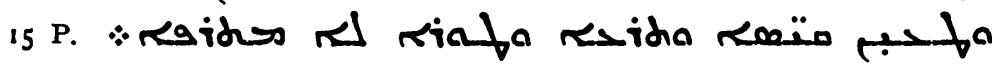

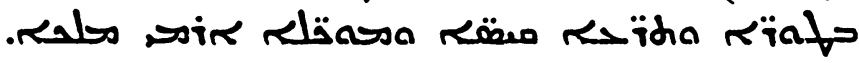
After these lines $P$. has the following:

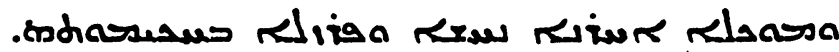
$\therefore$ Rodra ruasa ralra rasodia raid sir 


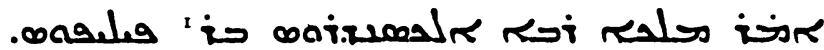

: 425

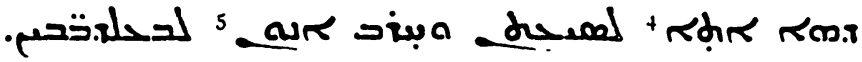

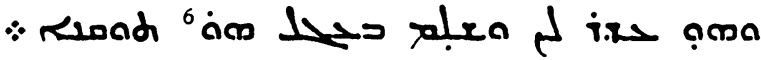

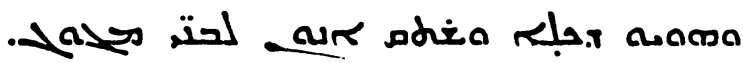

i:

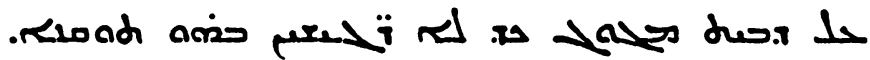

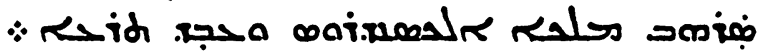

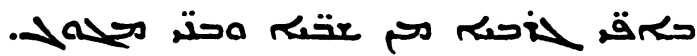

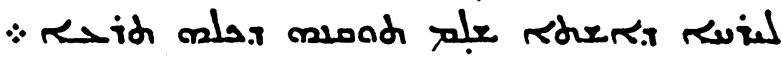
imdio

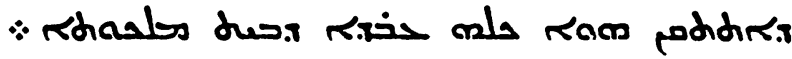
حخr.r

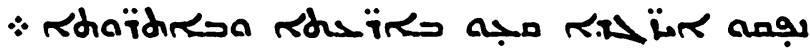
حظr.

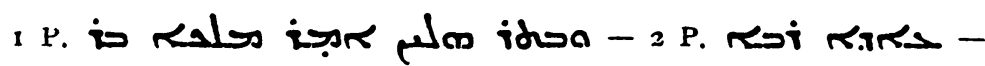

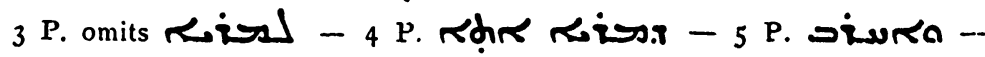

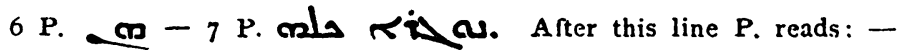

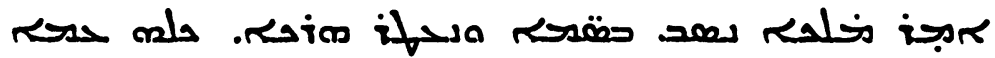

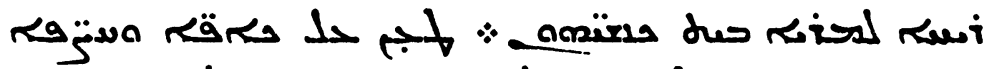

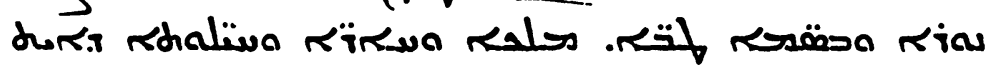

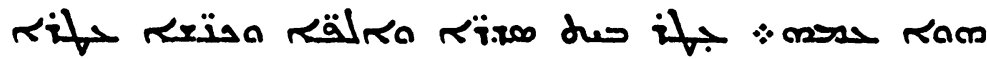

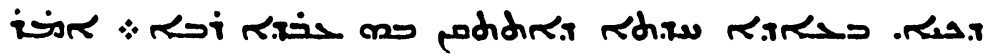

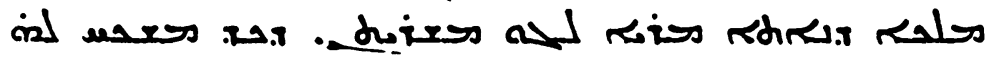
Ram

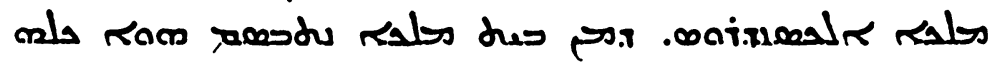




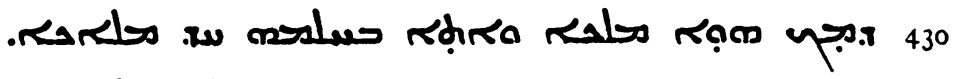

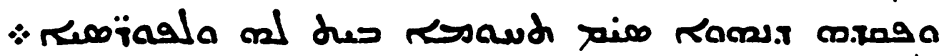
אוֹ

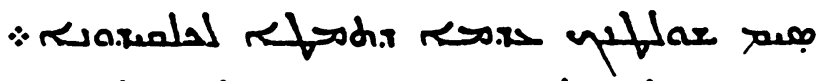

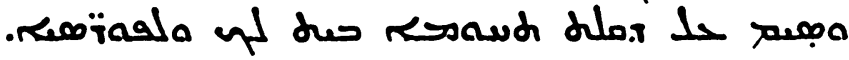

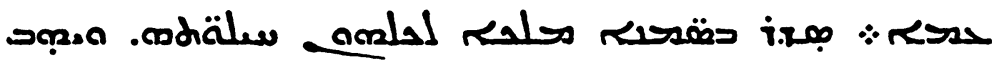

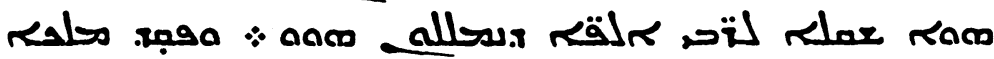

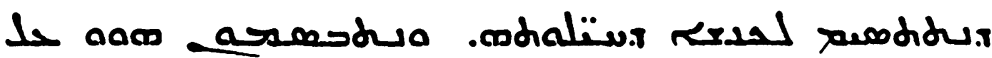
Kirsua riahs

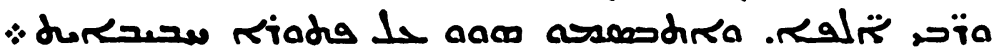
טسז.

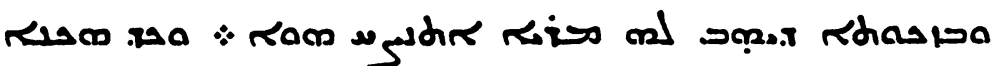

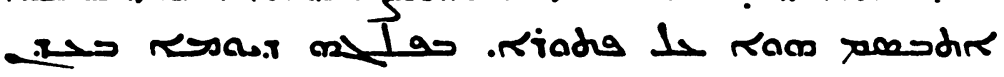

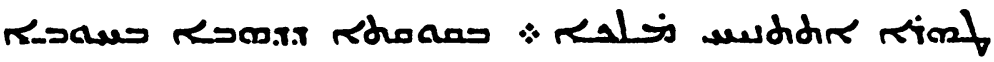

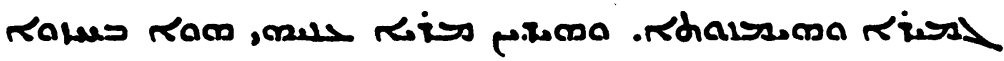

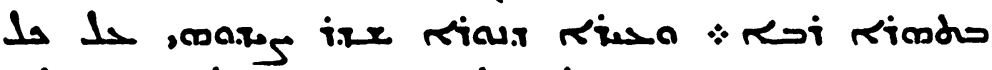

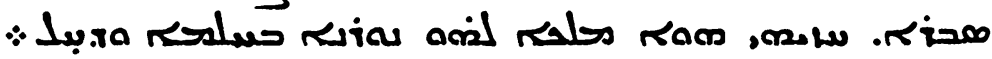

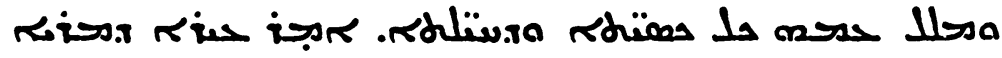

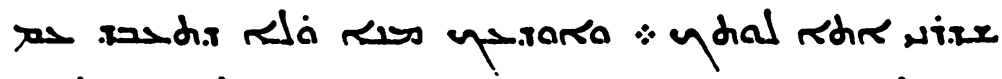

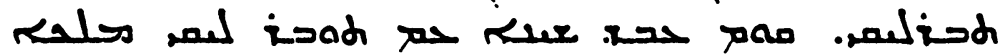

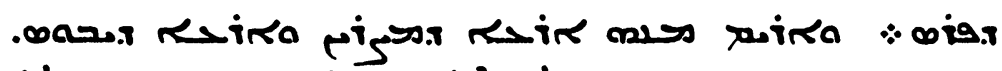
ס्र

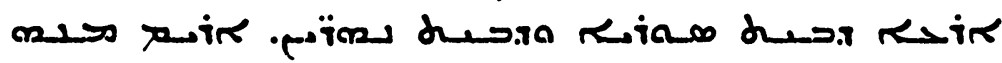

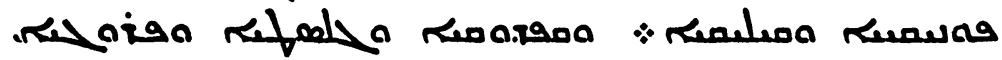

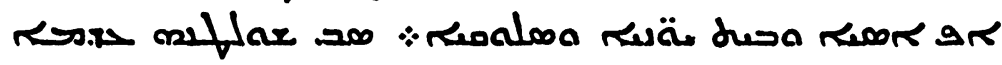

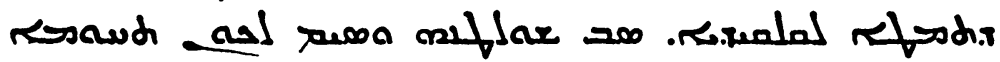
$\therefore$ مims ods 
" 435 אחקו

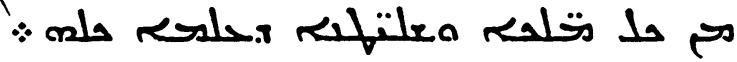

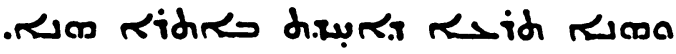
: 440

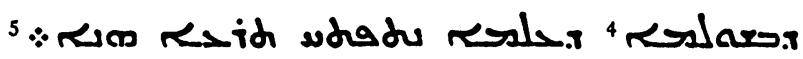

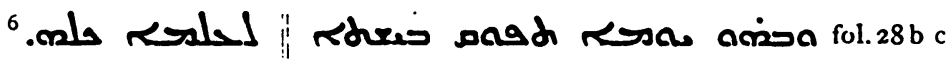
$\therefore$ Rdïلمa Rdï le ra rama 7 غ

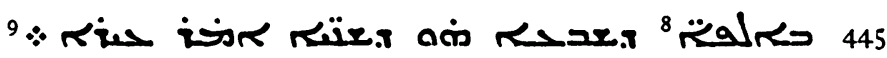
.

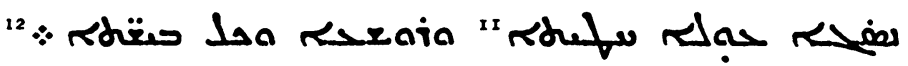

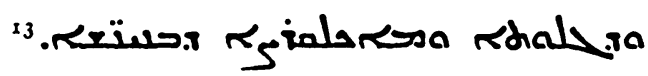

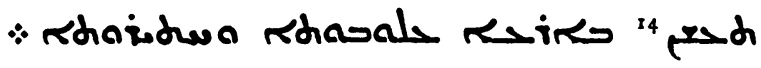
${ }^{15}$.Rhariaara Rhallia Rharsi ar $45^{\circ}$

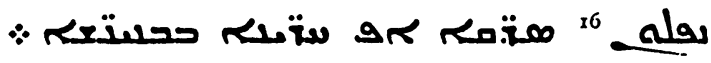

1 Here P. and L. again agree. - 2 P. שR - 3 P. RתiR-

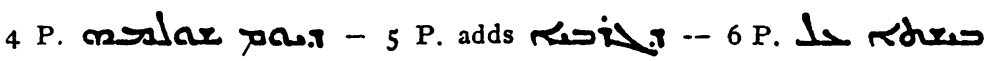
معت - 7 P. omits this line. - 8 P. .

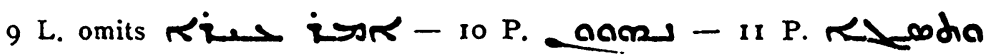

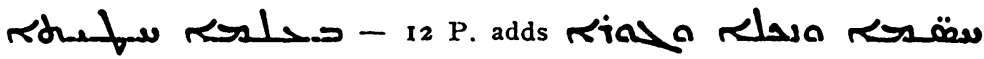

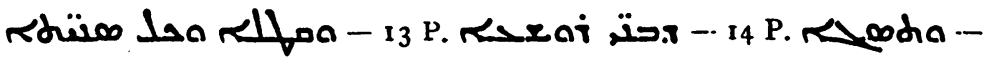
15 P. Rhioasa - 16 P. alasa. 
. Rin "saida rud racho

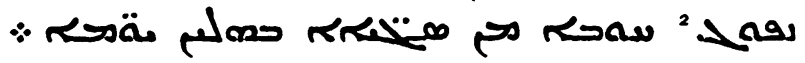

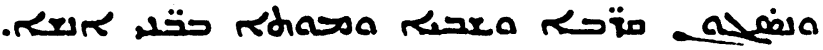
: 455

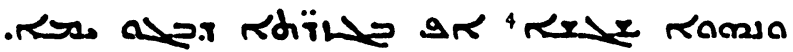
.2S a col.

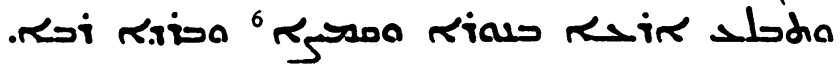

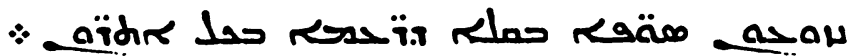
460 $\therefore$ مaras

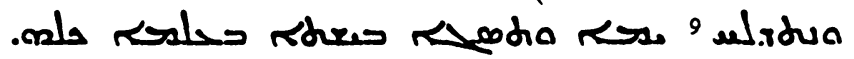

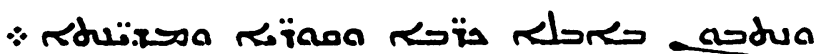

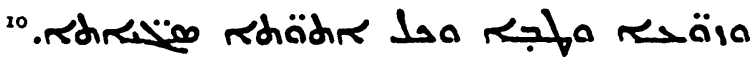
": *slar 465

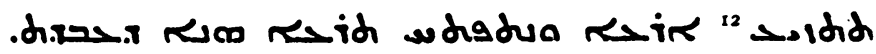
r

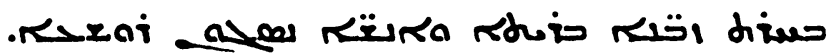

I P. Naida wark - 2 P. Naqa 3 P. Ridr Ridres angsa -

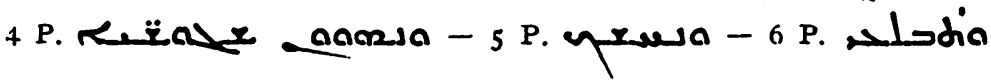

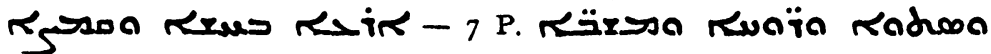

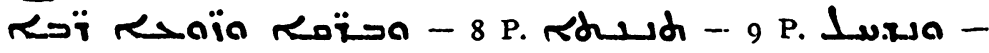

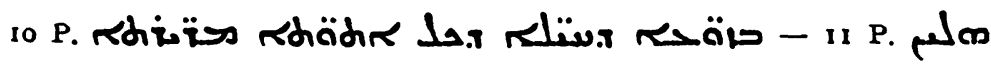

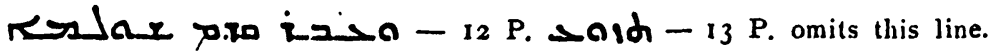




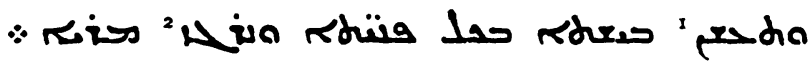

3.

$\therefore$ "

مختم محتא

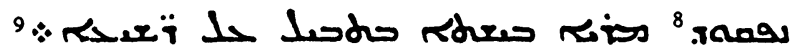

. Rid.

so

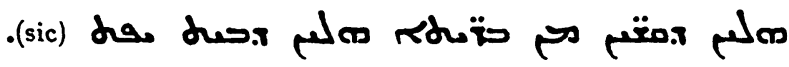

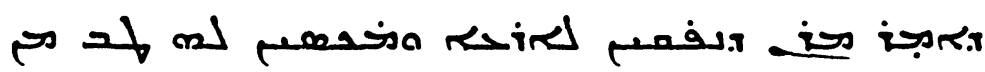

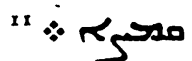

imd

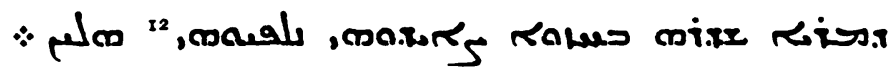
480

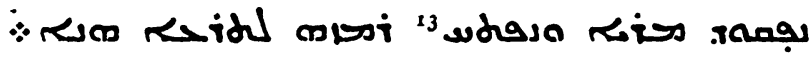

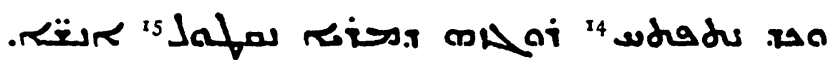

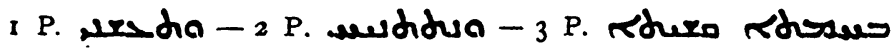

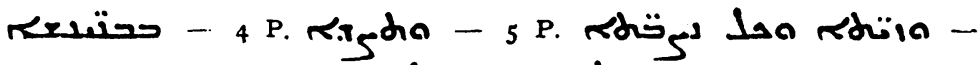

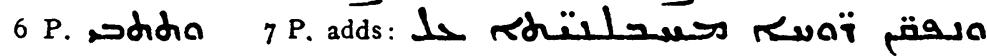

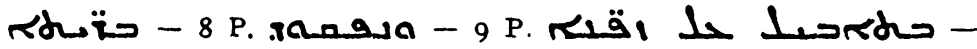
10 P. Jas sesa dada -

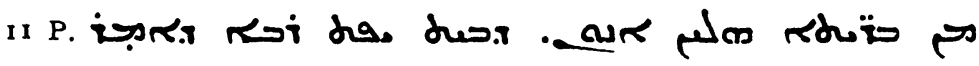
sir * 14 P. drudos a - 15 P. Jafou.s.

Zeitschr. f. Assyriologie, VI. 
נרוi' "هل

fol. $29 \mathrm{~b} \mathrm{col}$. I || سمله ז. 3 * 485

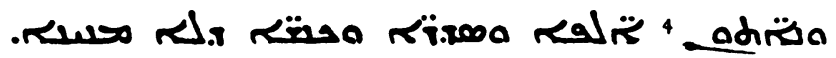

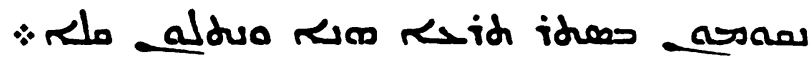

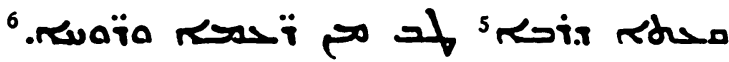

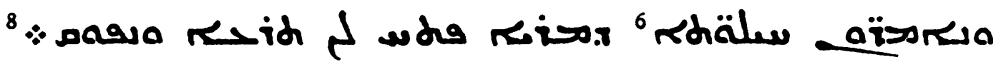
490

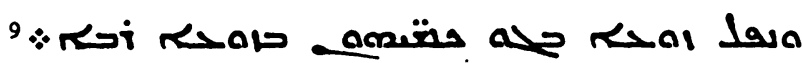

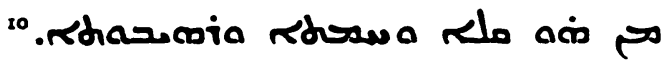

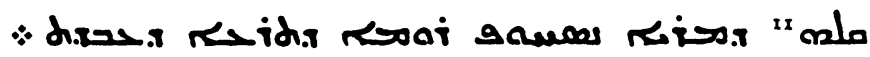
ת12.

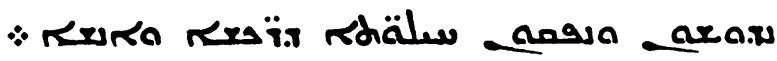

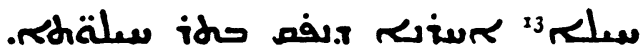

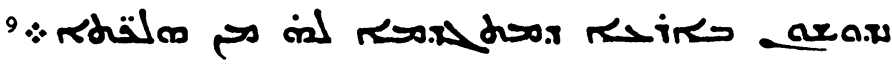
fol.29b col.2 14 "

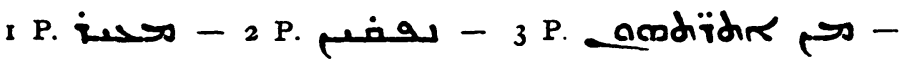

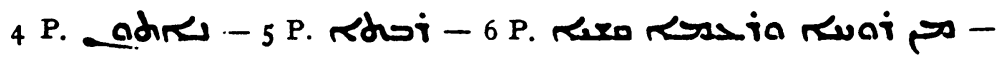
7 P. omits Rhaliv תin

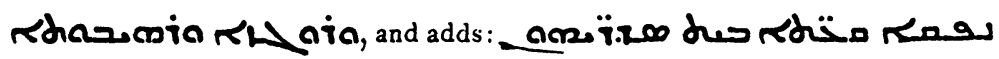

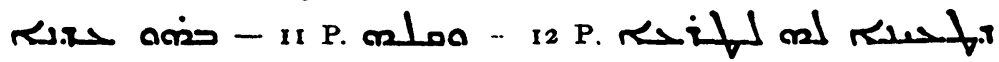

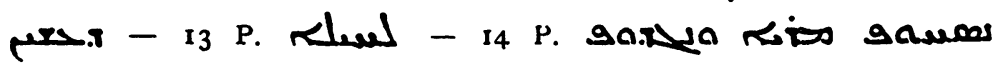
또. 


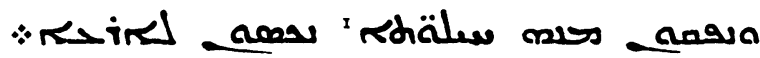

300

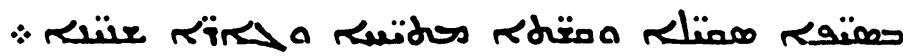

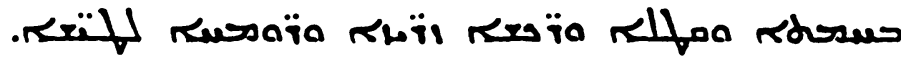

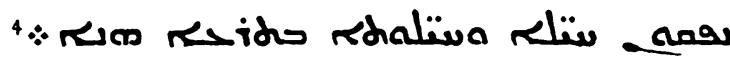
ז.

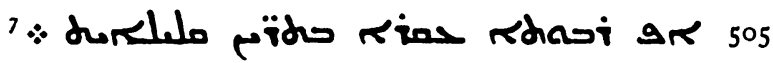
ais

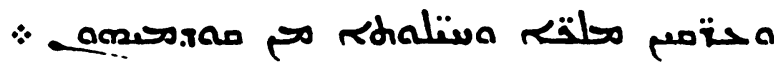

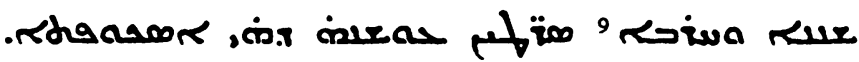

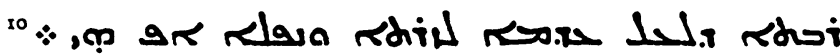
"2. 510

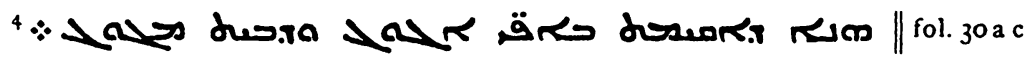

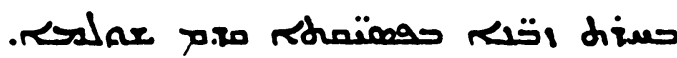
$\therefore$ Ri RAais Rid wdadu Riss misio a

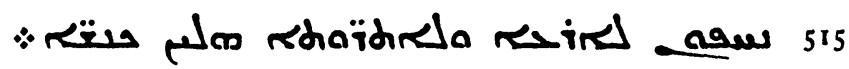
${ }^{3}$.

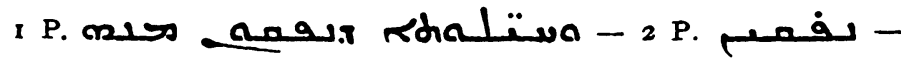
P. - 4 P. omits this line. - 5 P. - سطلم) -

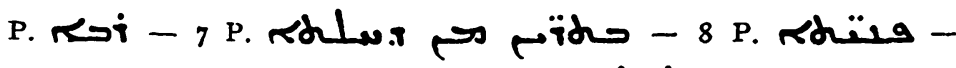
P. م.

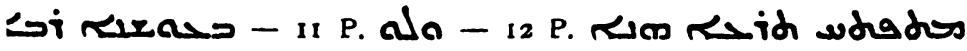

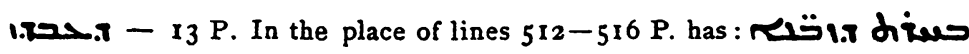
cines raمer.s. 


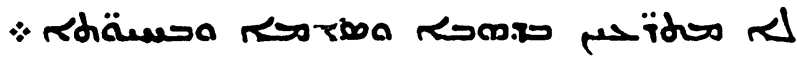

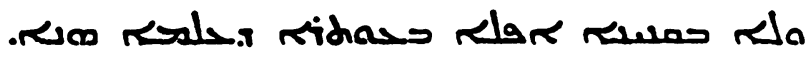

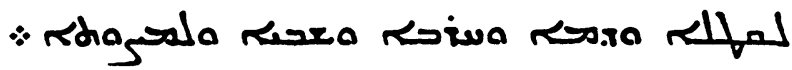

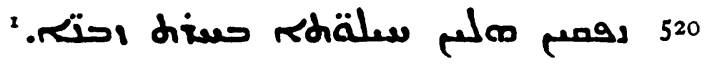

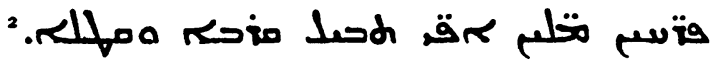

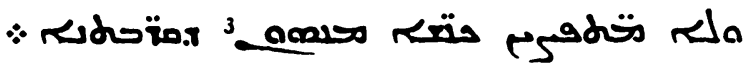
sir כ.

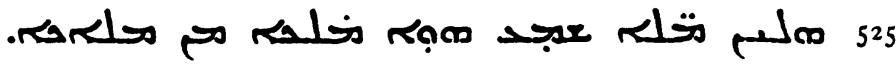
ז x

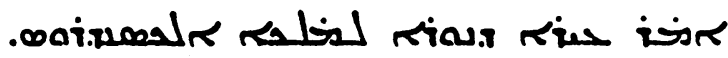

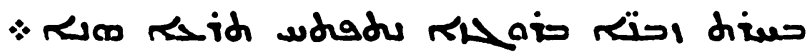

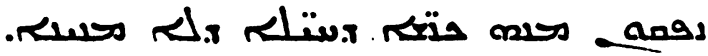
530 هل x. $\therefore$ :

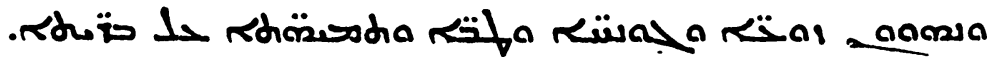

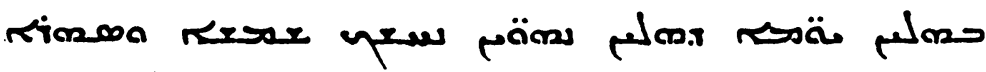

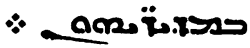

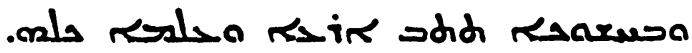

- Rdresa rezaia rlar ras

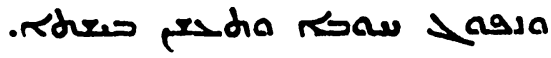

I In the place of lines 519 and 520 P. has: لم:

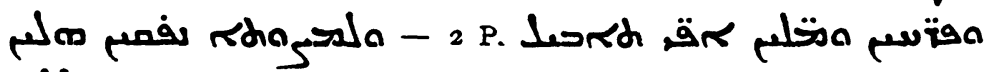

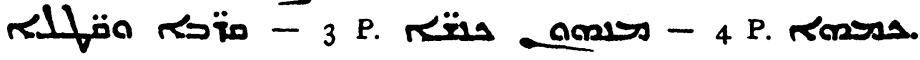


Alexander the Great and Gog and Magog.

393

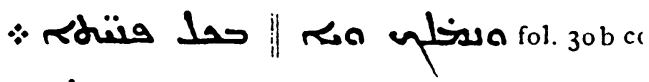

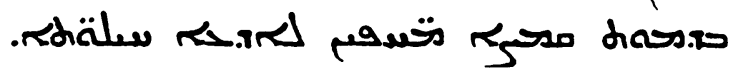
540

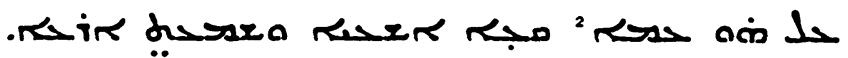
Ti.

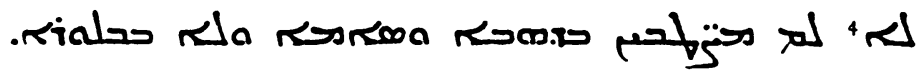
محalar

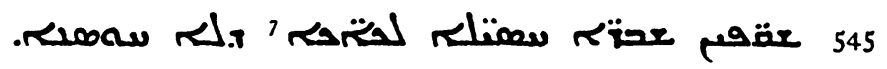
ملحه il

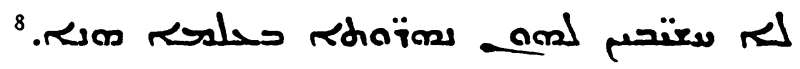

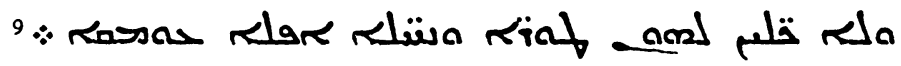

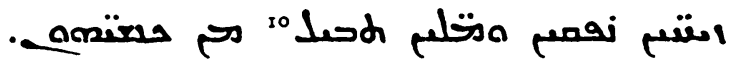
" 550 fol. 30 b co

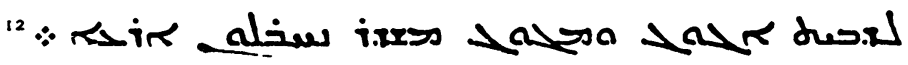

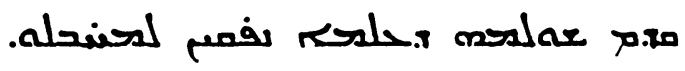

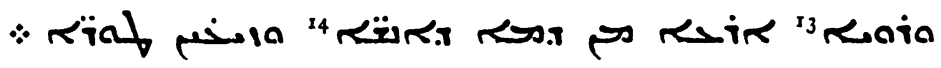
555

1 P. omits lines 524-540. - 2 P. RS as. - 3 P. omits this line. 4 P. Rd ul -

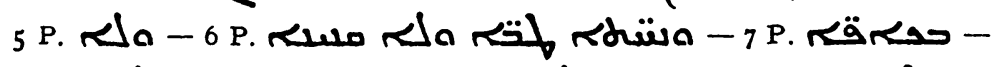
8 P. مله - 9 P. -

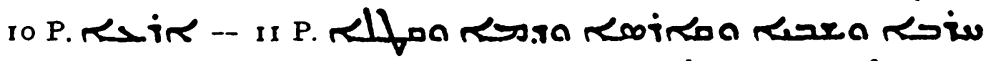

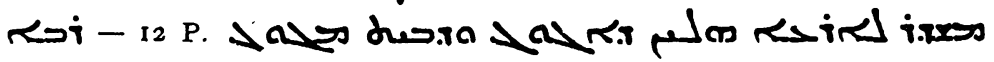

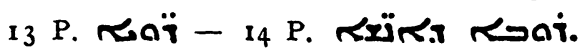

Brought to you by | New York University Boost Library Technical

Authenticated 


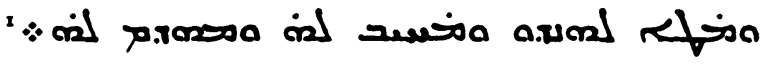

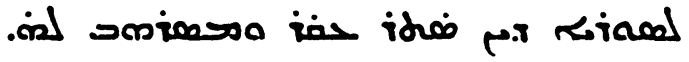

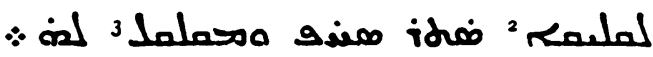

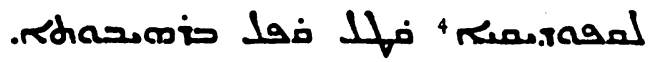

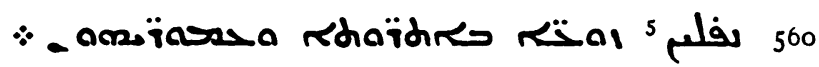

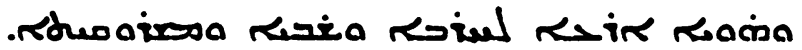

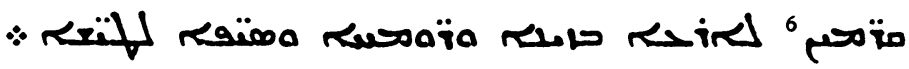

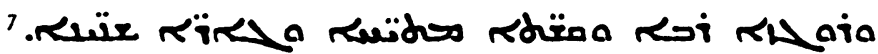

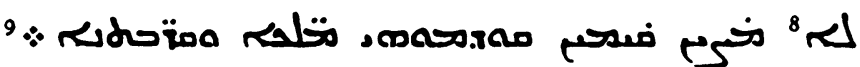
3 i a col. 1

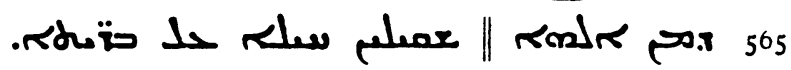

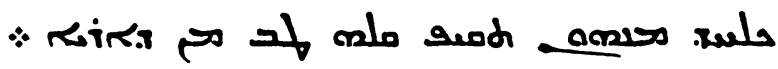
.rhasi مiw ams orio

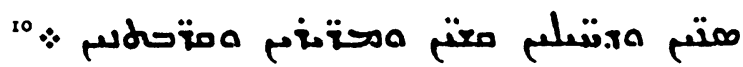

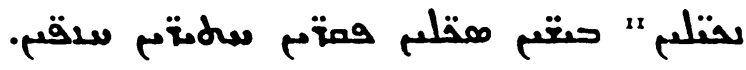
570

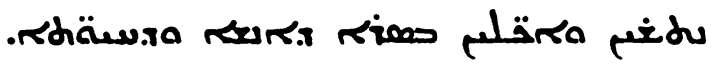

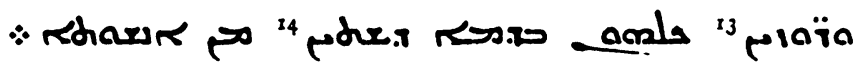

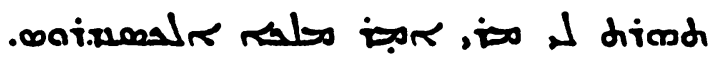

I P. id a d -

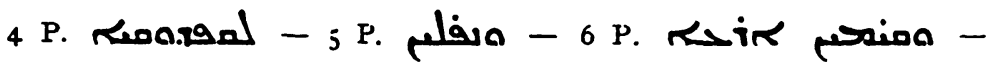
7 P. omits this line. - 8 P. لمa - 9 P. -

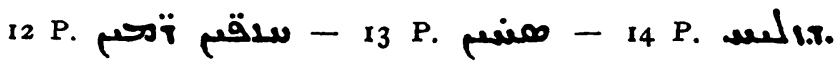




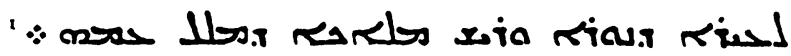

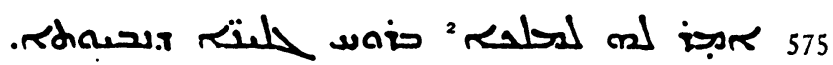

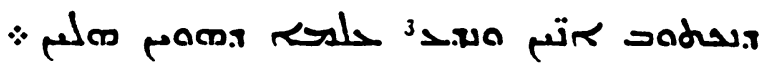

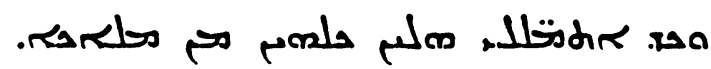

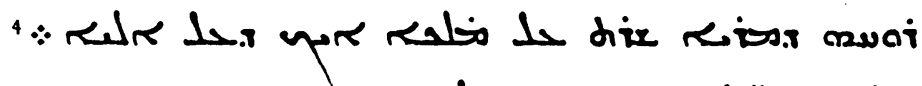

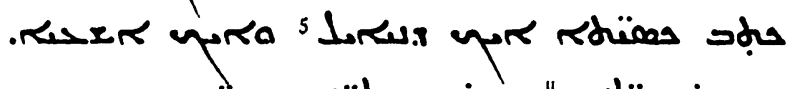
:

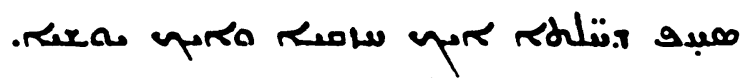

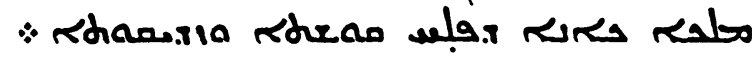
.

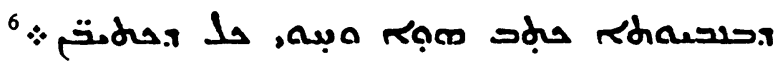
585 * amena

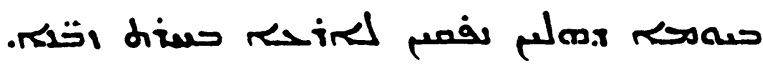

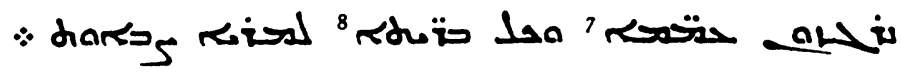

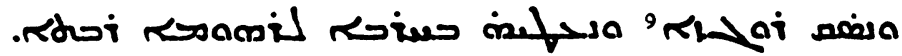

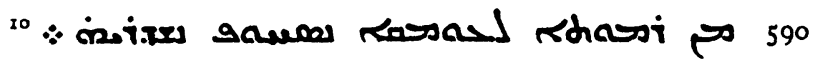
"

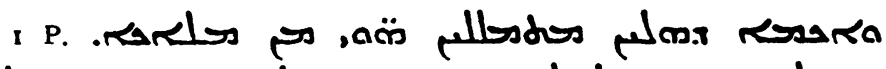

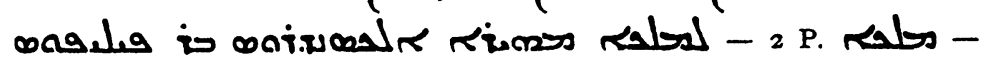

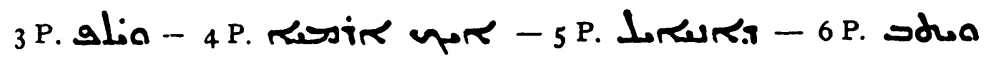

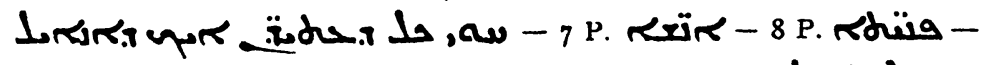

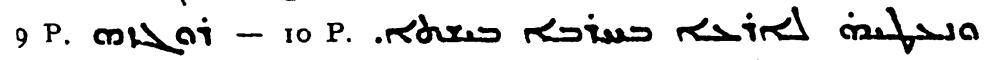
sameas rosal mbasi pohsi said - II P. omits his line. 


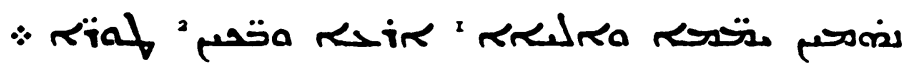

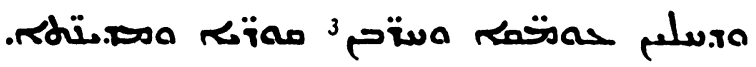

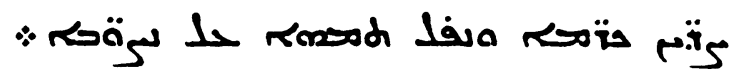

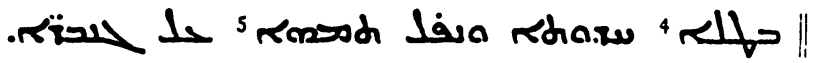
595 م متهم טتمى ${ }^{7}$

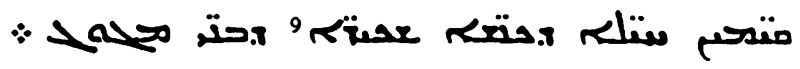

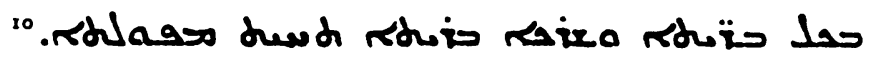

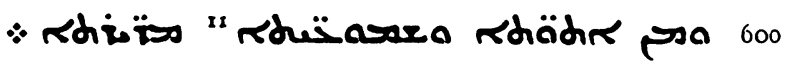

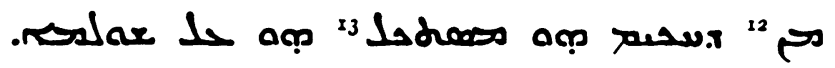

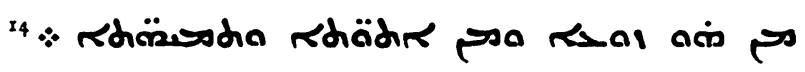

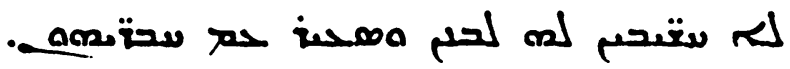
• 605 :

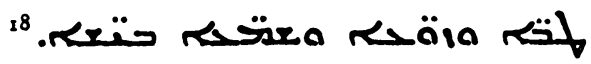

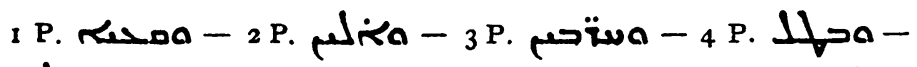

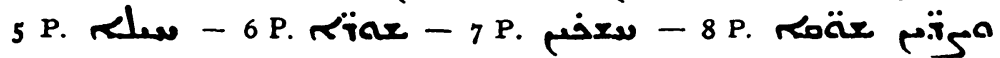

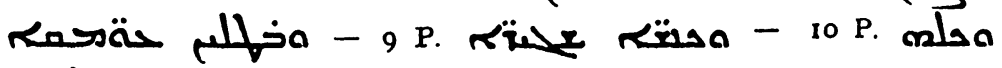

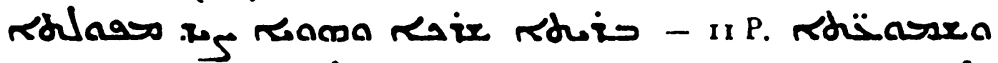

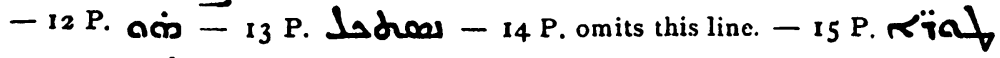
- 16 P. فلب - 17 P. 18 In the place of lines 606 and

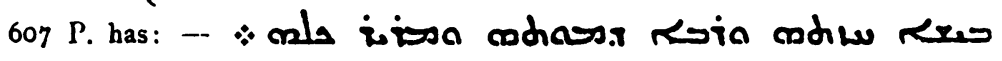

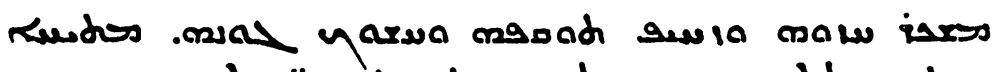

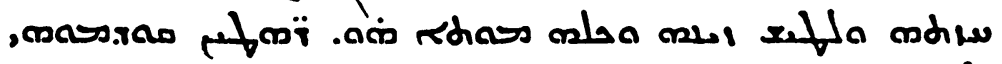

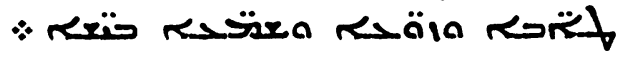




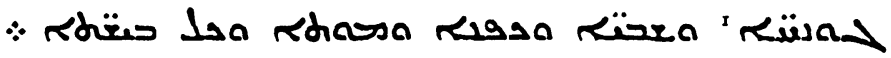

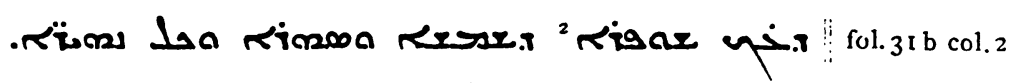
$\therefore$ Rhairsso ${ }^{3}$ R 610

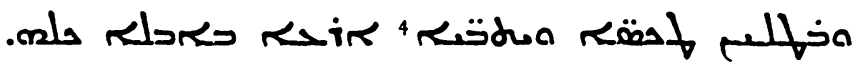

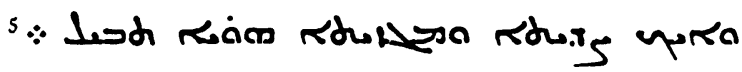
תing

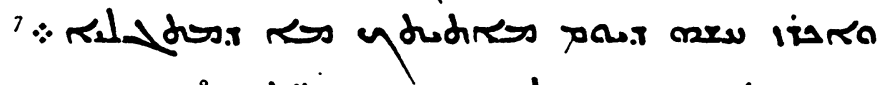

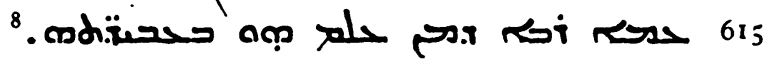

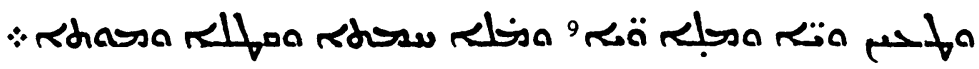

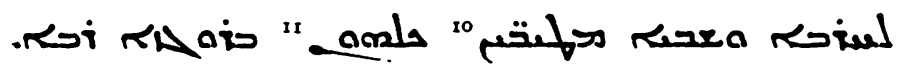

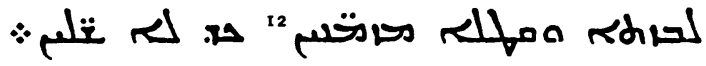
.

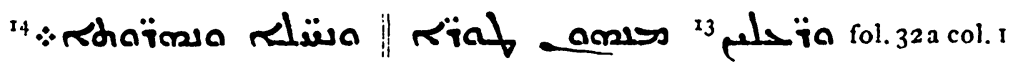

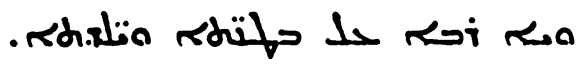

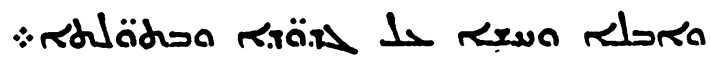

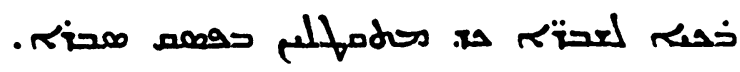

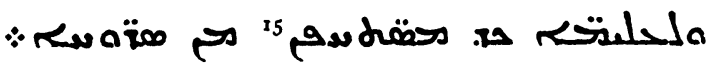

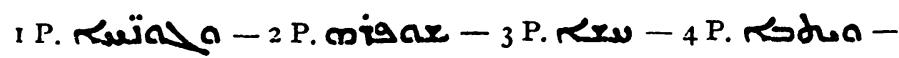

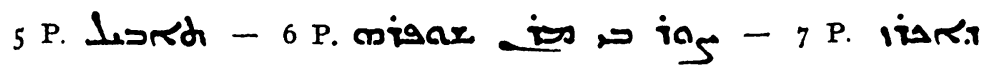
حרא ת -

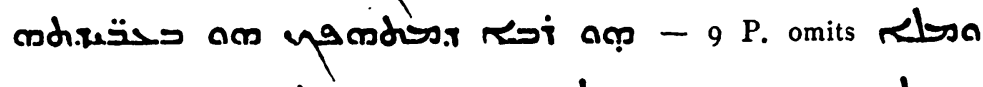

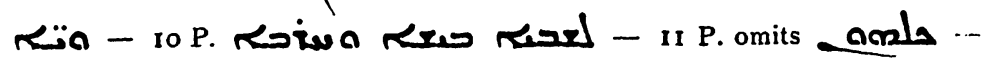

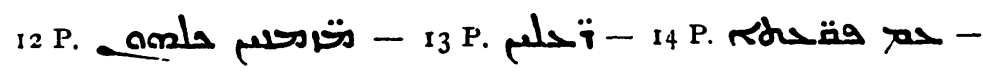

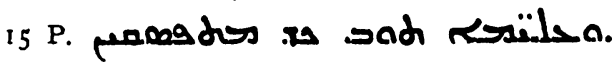




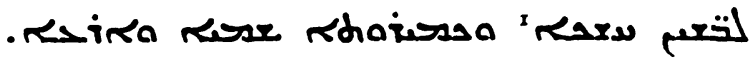
625

•

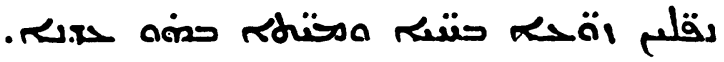

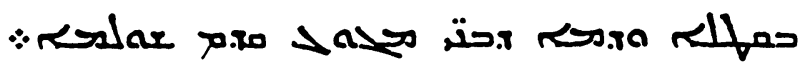

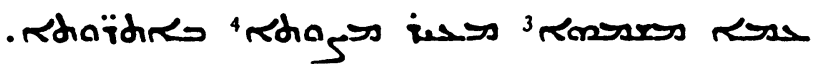
$\therefore$ م 630

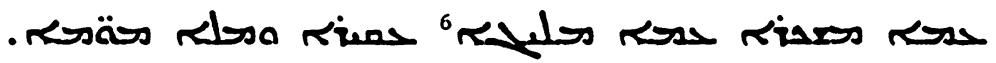

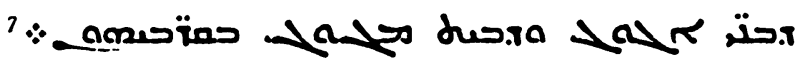
rix .32 a col. 2

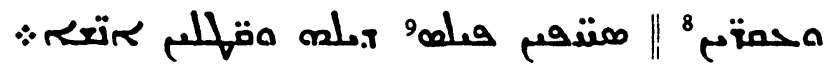
- 635

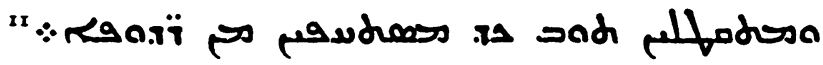

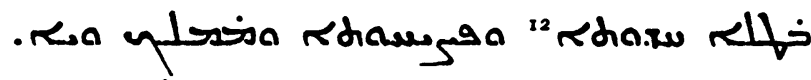

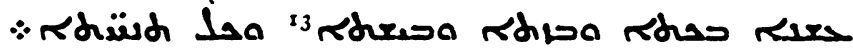

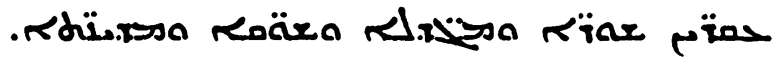

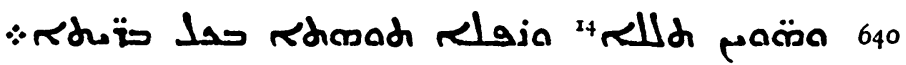

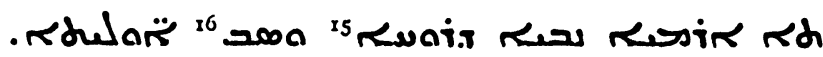

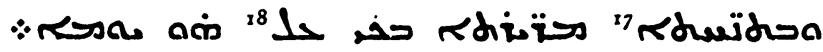

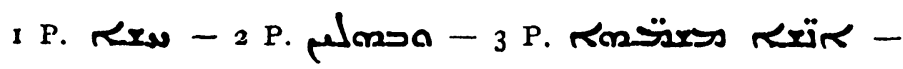

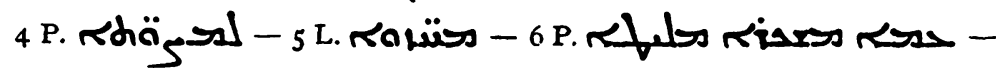
7 P.

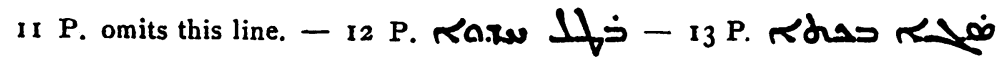

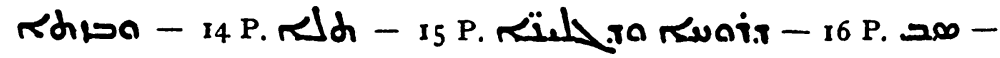
17 P. omits Rdüsdsa - 18 P. omits ل. 


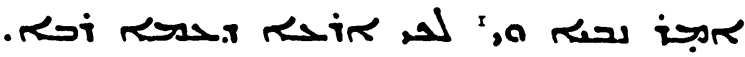

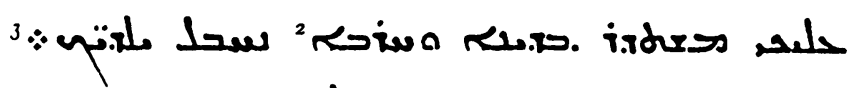

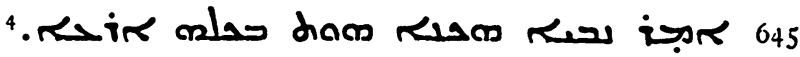

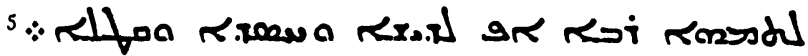

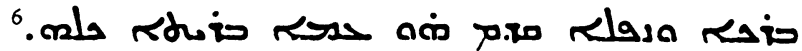

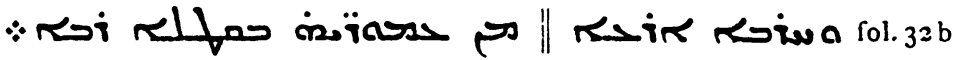

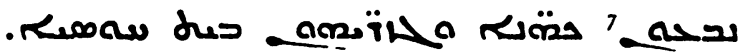

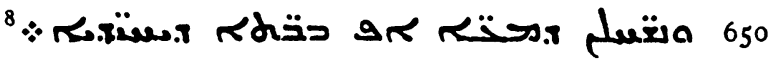

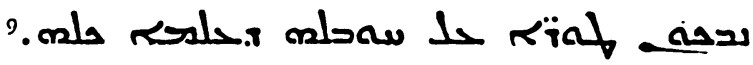

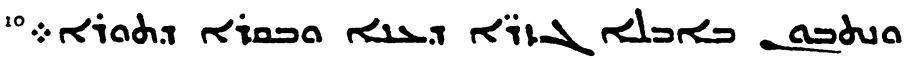

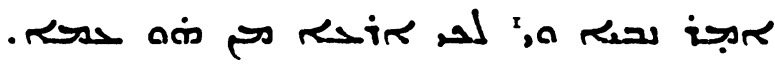
حه له

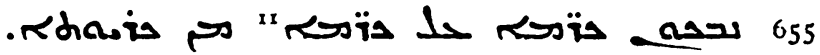

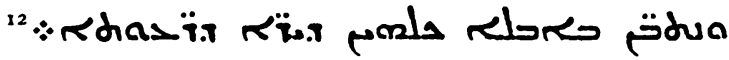

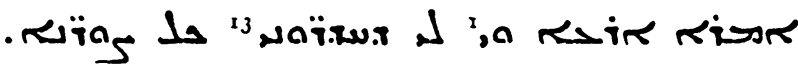

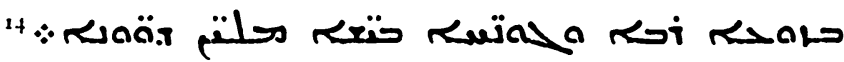

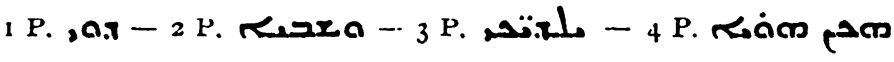

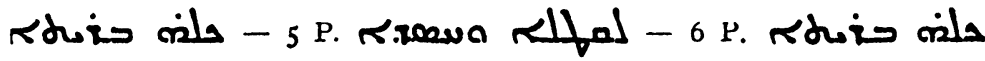

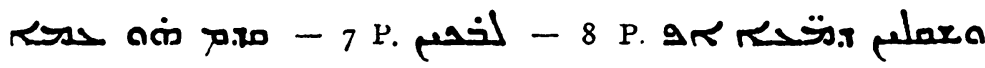

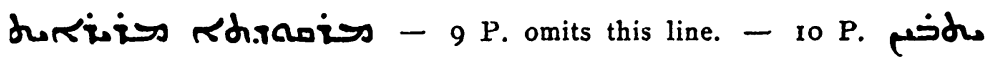

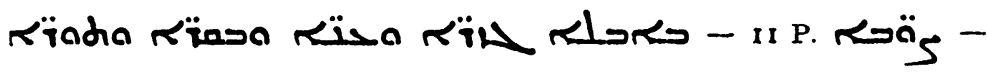

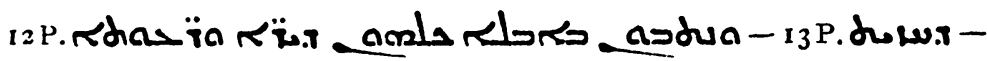

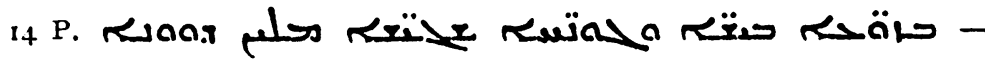


fol. $32 \mathrm{~b}$ col. 2

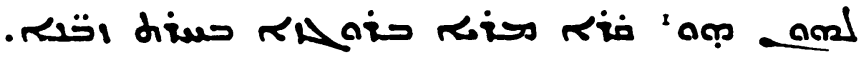
660

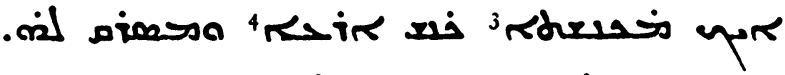
$\therefore$ in لـ

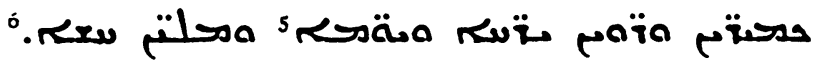

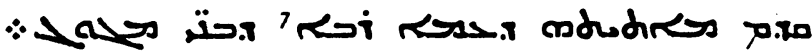

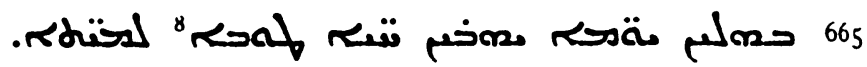

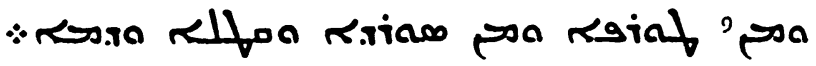
10. ת.

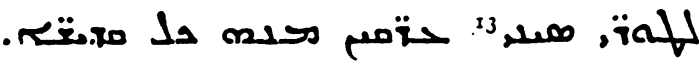

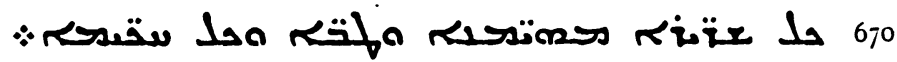

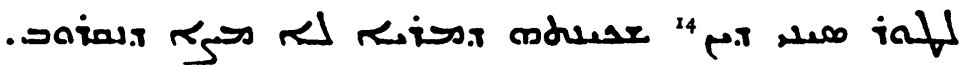

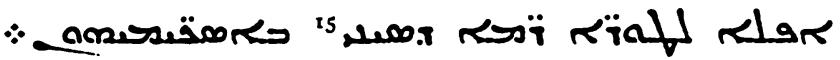
fol. 33 a col. $\mathrm{t}$

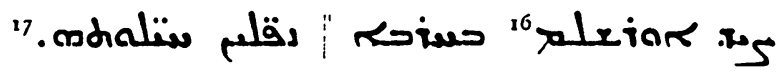

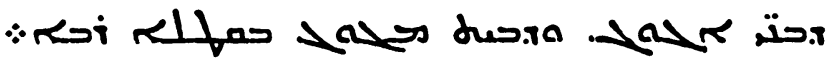

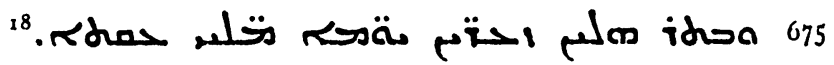

I P. id - 2 P. omits this line. - 3 P. .

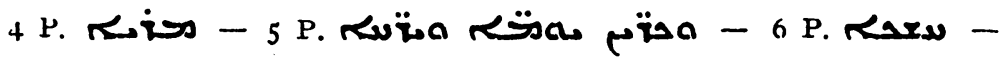
7 P. مسلم - 8 P. P.

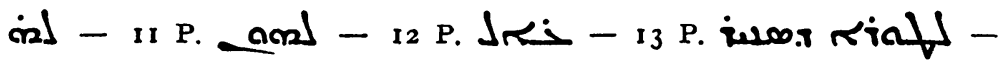

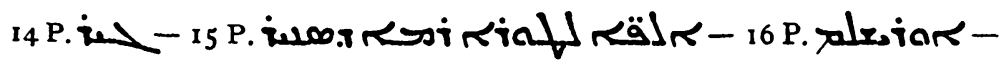
17 P. - 18 P. - سملعم أنحب - 
متركم " "3.

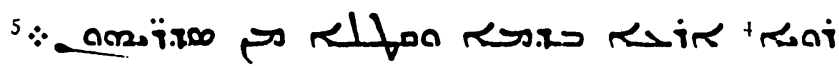

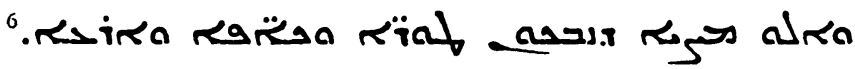
680

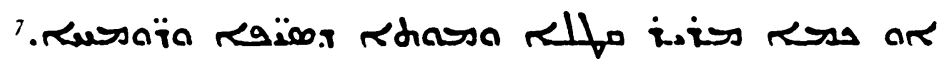

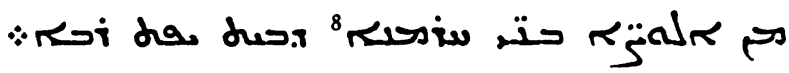
.

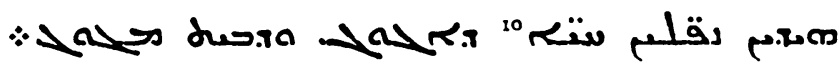
685 د2:

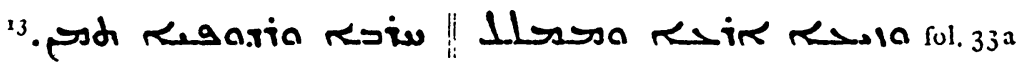
$\therefore$ : ".

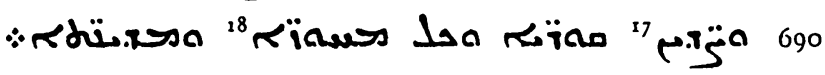

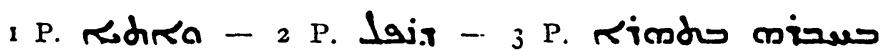

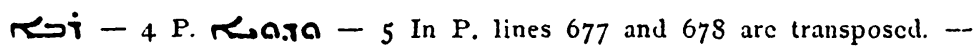

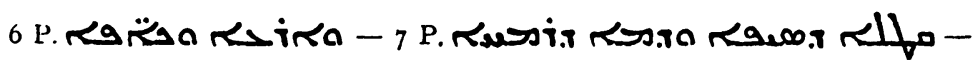
S P. נaفr

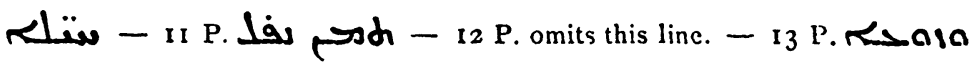

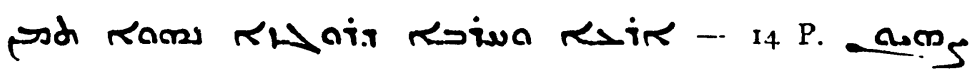

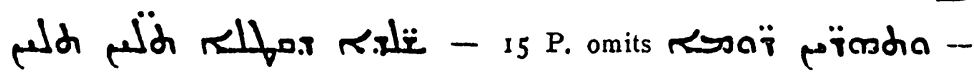
16 P. م- 17 P. 


\section{ז.

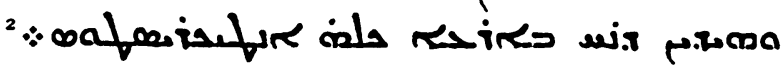

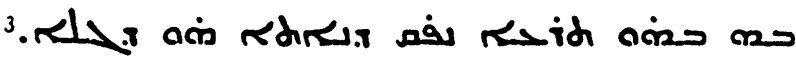
•

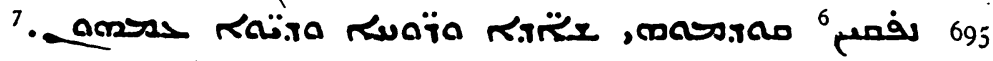

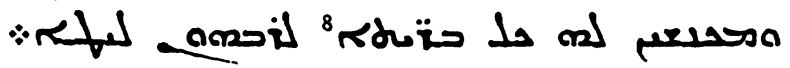

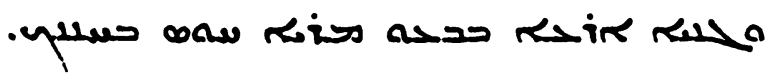

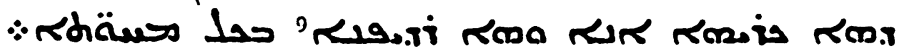

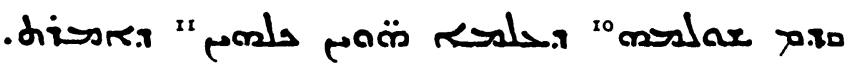
700 |m

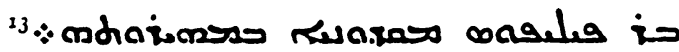

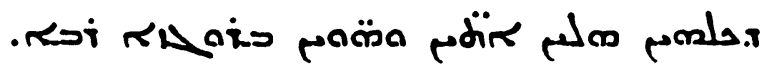

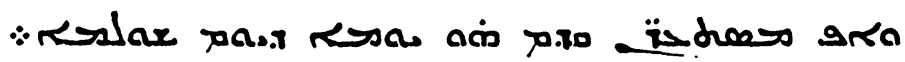

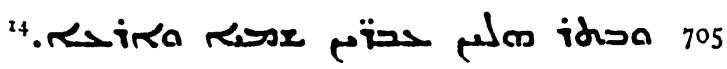

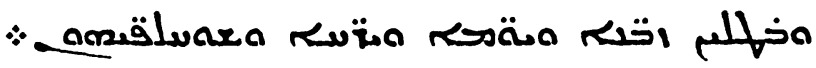

I In the place of lincs 690 and 691 P. has

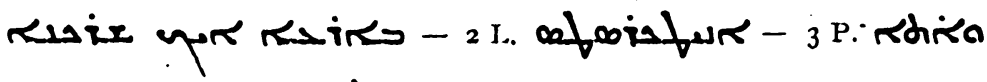
7 P. ת

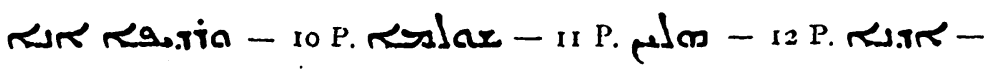
13 P. omits this line. - 14 In the place of lines 703-705 P. has pacas

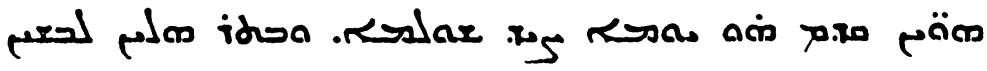
Rina Ress new. 


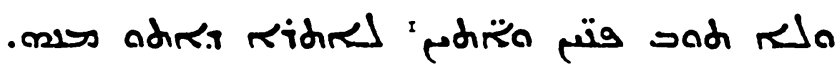

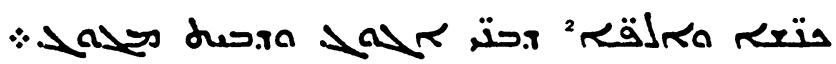

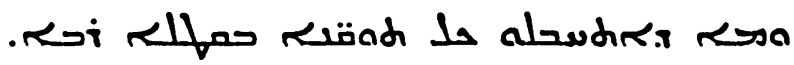

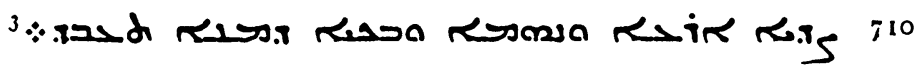

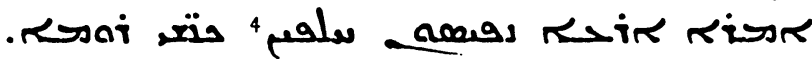

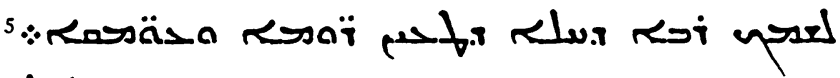

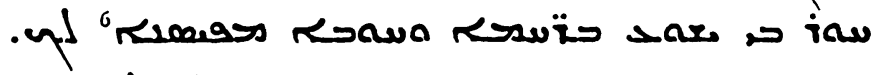

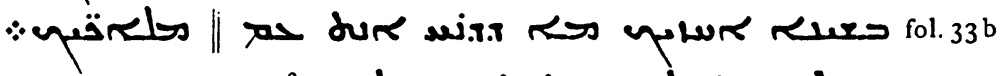
715

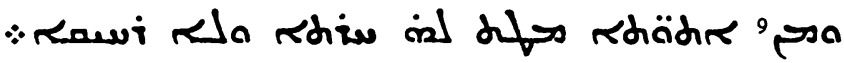

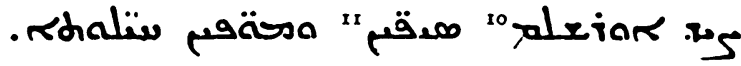

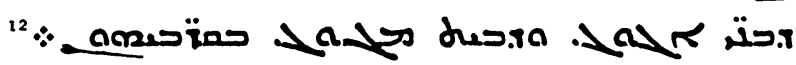

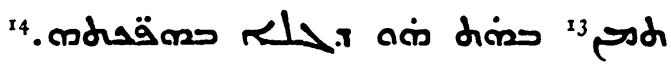
${ }^{17}$ : Rhoinas. R R R 720

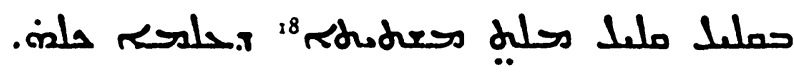

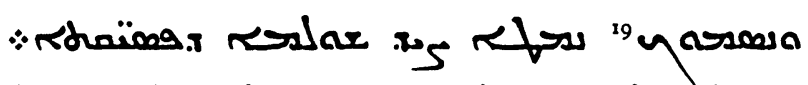

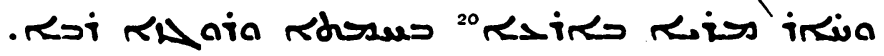

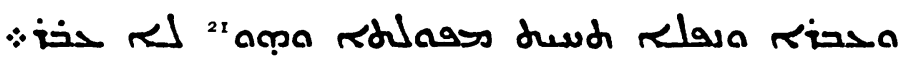

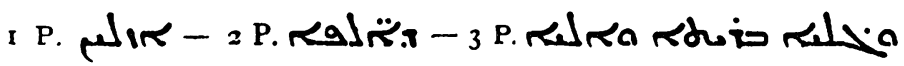

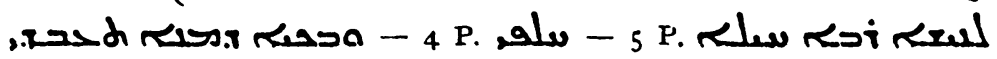

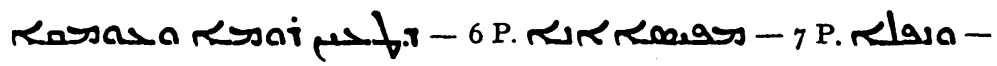
8 P. غ. 12 P. כ- -

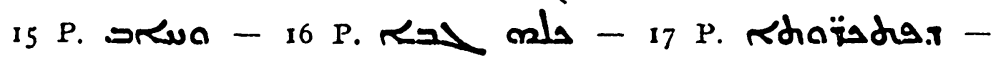

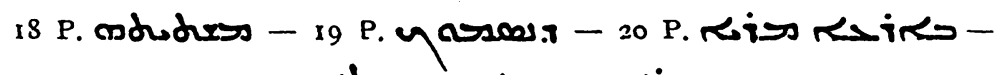

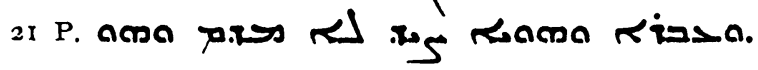


i25

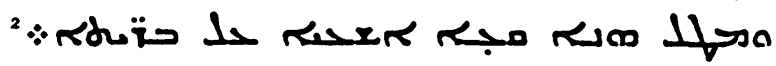
مa $\therefore$ مrina Rin idhod u صiي

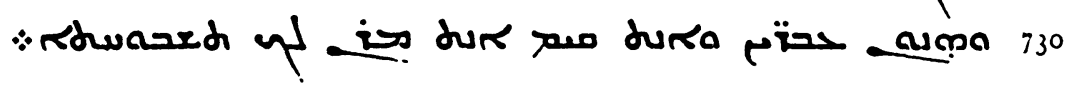

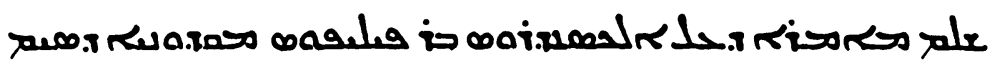

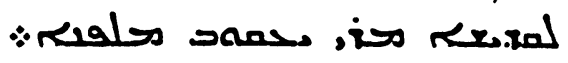

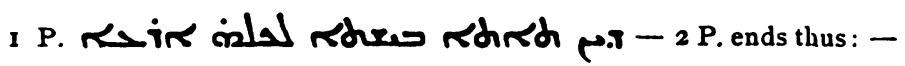

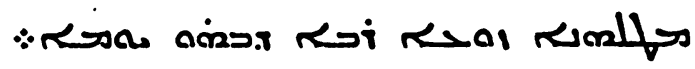

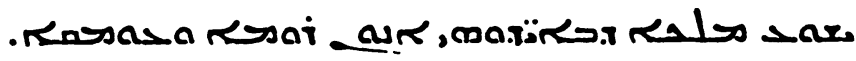
: תito

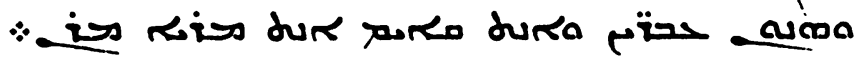
rar

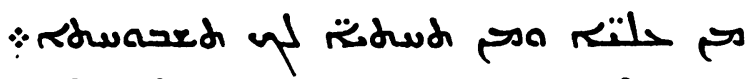
asp حí - Rdoïhra amsiass

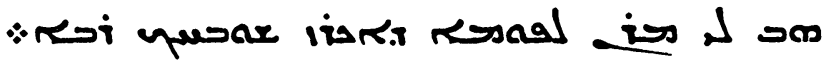

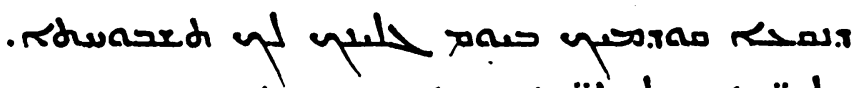
- Rasar ros rädala noirala

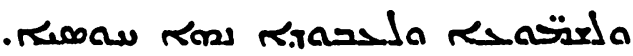

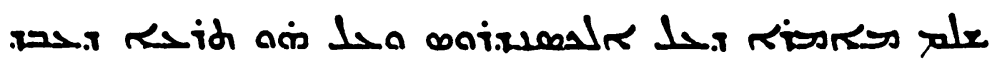
كمقة 